\title{
Effect of the armor crest freeboard relative to the crown wall freeboard on wave overtopping for simple rubble mound slopes
}

\author{
Berguzar Oztunali Ozbahceci ${ }^{\mathrm{a}, *}$, Engin Bilyay ${ }^{\mathrm{b}}$ \\ ${ }^{\text {a }}$ Izmir Institute of Technology, Faculty of Engineering, Department of Civil Engineering, Izmir, Turkey \\ ${ }^{\mathrm{b}}$ Yuksel Proje, Ankara, Turkey
}

\section{A R T I C L E I N F O}

\section{Keywords:}

Wave overtopping

Armor crest freeboard

Crown wall freeboard

Rubble mound breakwater

Hydraulic model experiment

Prediction formula

\begin{abstract}
A B S T R A C T
Several studies have been carried out to investigate the effect of crest parameters on the wave overtopping for armored slopes with crown walls. However, the effect of the armor crest freeboard is still under question. In this study, for the first time, a series of hydraulic model experiments are conducted specifically to investigate how the armor crest freeboard relative to the crown wall freeboard affects the wave overtopping rate. Experimental results indicate that while the armor crest freeboard lower than the crown wall freeboard is giving larger overtopping, higher armor crest freeboard is reducing the overtopping. However, this reduction is not same as the reduction due to the increase in the crown wall freeboard. The reason may be the porosity of the armor crest. For the first time, a new correction factor is proposed to describe the change in the wave overtopping due to the armor crest freeboard by using experimental results. The correction factor $\mathrm{C}_{\mathrm{Ac}}$ is applied to cover the effect of armor crest freeboard in the predictions of EurOtop (2016). The verification study present that overtopping rate predictions of corrected EurOtop (2016) are more consistent with the measured rate results compared to the predictions of the original formula, if the armor crest freeboard is not equal to the crown wall freeboard.
\end{abstract}

\section{Introduction}

Wave overtopping is defined simply as the flow of sea water over the crest of a coastal structure due to wave run-up, wave breaking on the structure and wind action (EurOtop, 2016). Therefore, the structure crest freeboard, $R_{s c}$ which is the highest point of the structure is the most important structural parameter affecting the wave overtopping. For rubble mound slopes, usually a crown wall (wave wall) is used not only to reduce wave overtopping but also to protect lee-side, to create access to the breakwater and to end the armor layer in a good way (Bradbury et al., 1988). If there is a crown wall, then the crest freeboard of the crown wall is represented by $R_{c}$ as it is shown in Fig. 1 .

The crest freeboard of the armor layer is represented as $A_{c}$. Crest parameters $A_{c}, R_{c}$ and another one, crest berm width, $G_{c}$ are indicated in Fig. 1. If a crown wall is designed at the same level as the armor crest, then $R_{c}=A_{c}$. However, sometimes it may not be possible due to economical reasons. If run-up levels are high especially for severe climate conditions, in order to equalize the crown wall freeboard and the armor crest freeboard, the core layer should be leveled up or more filter layers should be constructed which can increase the cost dramatically. Instead of it, the crown wall freeboard is increased, but, it is advised not to design the crown wall much higher than the armor crest considering the wave impact loads on the wall (EurOtop, 2016). On the other hand, sometimes $A_{c}>R_{c}$ in case of unnecessary high wall so that the crown wall is just used as access road.

Several studies have been carried out to investigate the effect of crest parameters on wave overtopping. Through the project, namely 'CLASH', much of the experimental data regarding wave overtopping throughout the world was collected. Database consist 10,532 overtopping tests, originating from 163 independent test series (Verhaeghe, 2005). Each test was characterized by 31 parameters (11 hydraulic, 17 structural and 3 general). It can be possible to filter the tests by using these parameters. In order to find the number of tests corresponding to cases with $A_{c}=R_{c}, A_{c}>R_{c}$ and $A_{c}<R_{c}$ for simple armored slopes (no berm, slope of the structure $=\cot \alpha=1-4$ ) with permeable core (permeability and roughness coefficient $<0.55$ ), the data can be filtered according to the structure geometry and properties. The total number of tests for simple armored slopes with permeable core under perpendicular wave attack is 3384 . The crown wall freeboard, $R_{c}$ is at the same level as the armor crest freeboard, $A_{c}$, or it is higher than $A_{c}$ in 2590 tests. Detailed explanation of some of these tests are given in Aminti and Franco (1988), Bradbury et al. (1988), Pedersen (1996), Pearson et al. (2004), Geeraerts and Willems (2004). After CLASH database was published, Coeveld et al. (2006) and Smolka et al. (2009)

\footnotetext{
* Corresponding author.

E-mail addresses: berguzarozbahceci@iyte.edu.tr (B. Oztunali Ozbahceci), EBILYAY@yuksel.com.tr (E. Bilyay).
} 


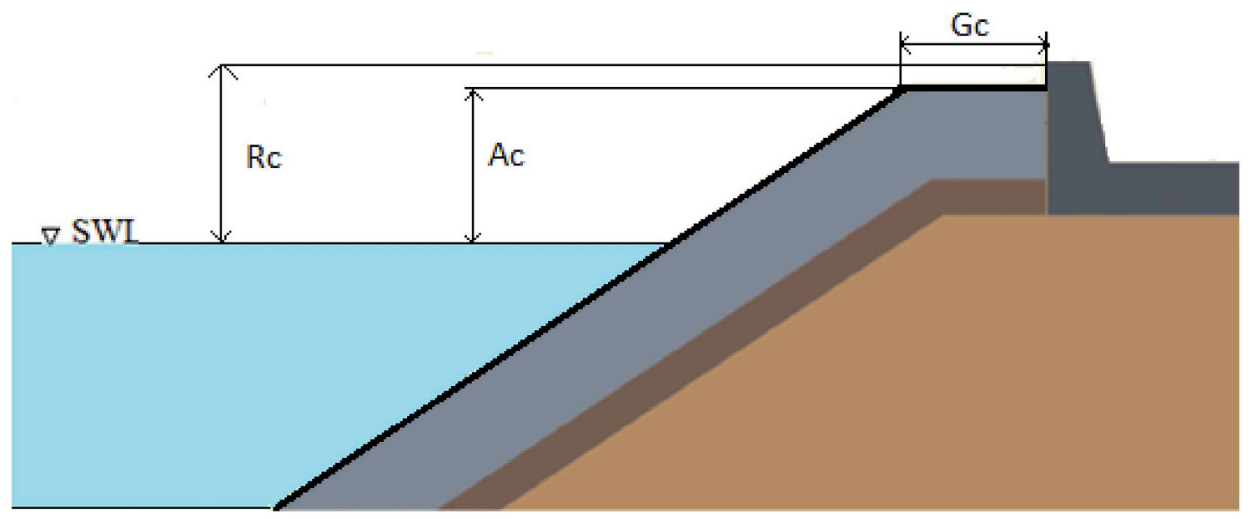

Fig. 1. Crest parameters: crown wall freeboard $R_{c}$, armor crest freeboard $A_{c}$, armor crest berm width, $G_{c}$.

Table 1

The application range of Pedersen (1996), Molines and Medina (2015b), EurOtop (2016).

\begin{tabular}{llll}
\hline Parameter & Pedersen (1996) & Molines and Medina(2015b) & EurOTop (2016) \\
\hline $\mathrm{Ir}$ & $1.10-5.10$ & $1.65-7.21$ & $>2.00$ \\
$\mathrm{R}_{\mathrm{c}} / \mathrm{H}_{\mathrm{m} 0}$ & $0.60-2.70$ & $0.52-3.75$ & $>0.00$ \\
$\mathrm{~A}_{\mathrm{c}} / \mathrm{R}_{\mathrm{c}}$ & $0.38-1.00$ & $0.38-1.38$ & 1.00 \\
$\mathrm{G}_{\mathrm{c}} / \mathrm{H}_{\mathrm{m} 0}$ & $0.96-2.80$ & $0.00-3.50$ & $>0.75$ \\
$\cot \alpha$ & $1.50-3.50$ & $1.19-4.00$ & $1.33-2.00$ \\
\hline
\end{tabular}

(Molines and Medina, 2015a) also tested the wave overtopping for lower armor crest freeboard cases $\left(A_{c}<R_{c}\right)$. Besides, there are 790 tests conducted with higher armor crest freeboard (for example: Kortenhaus et al., 2004). However, no experiment has been conducted specifically to investigate the effect of armor crest freeboard relative to crown wall freeboard on overtopping by testing all $A_{c}>R_{c}, A_{c}<R_{c}$ and $A_{c}=R_{c}$ cases for simple armored slopes with a crown wall.

\subsection{Prediction tools including armor crest freeboard}

It is very important to predict the wave overtopping during the design of coastal structures. In most cases, the waves and the overtopping process are not so simple and well-controlled so that analytical methods cannot give reliable predictions (Van der Meer et al., 2010). The prediction methods, therefore, typically have basis on the empirical formulas derived by experimental studies or use some other methods like artificial neural network. Empirical formulas relate the overtopping response to the main wave and structure parameters for different structure types (EurOtop, 2016).

There are various overtopping prediction formulas: Owen (1980), Bradbury and Allsop (1988), Aminti and Franco (1988), Pedersen and Burcharth (1992), Van der Meer and Janssen (1995), TAW (2002), EurOtop $(2007,2016)$. However, those overtopping formulae do not include the crest parameters except structure crest freeboard, $R_{s c}$, but are based on a simple power or exponential functions with reduction coefficients. 'Wave Overtopping Manual' (EurOtop, 2007) was produced by covering the formulas and some data of CLASH project. For simple mound breakwaters which have slopes $1 / 2$ or steeper, EurOtop (2007) gives an overtopping prediction formula including the structure crest freeboard $R_{s c}$ and the reduction factor to account the surface roughness and permeability. Pre-released version of the second edition of EurOtop Manual was published in 2016. In this new edition, it is seen that the formula is modified for rubble mound slopes and given as:

$Q^{*}=\frac{q}{\sqrt{g H_{m 0}^{3}}}=0.09 \exp \left(-\left(1.5 \frac{R_{s c}}{H_{m 0}} \frac{1}{\gamma_{f} \gamma_{\beta}}\right)^{1.3}\right)$

where; $\mathrm{q}=$ the mean overtopping rate, $\mathrm{H}_{\mathrm{m} 0}=$ spectral wave height,
$R_{s c}=$ structure crest freeboard, $\gamma_{f}$ and $\gamma_{\beta}$ are reduction factors to account respectively for the surface roughness together with permeability and oblique waves. $\gamma_{\mathrm{f}}=0.4$ for rock and $\gamma_{\beta}=1.0$ for perpendicular wave attack.

In Eq. (1), $R_{s c}=\max \left(R_{c}, A_{c}\right.$ ) (EurOtop, 2016). Therefore when $A_{c}>R_{c}, R_{s c}=A_{c}$ and it is assumed that the effect of $A_{c}$ on the overtopping rate is same as the effect of $R_{c}$. On the other hand, it is suggested that there is not any effect of $A_{c}$, when $A_{c}<R_{c}$ since $R_{s c}=R_{c}$. In fact, Schüttrumpf et al. (2010) and EurOtop (2016) underline that no formula is present to cope with such situations that $A_{c} \neq R_{c}$, unless the Neural Network prediction method is used.

The first wave overtopping prediction formula including the armor crest freeboard, $A_{c}$, belongs to Pedersen (1996). It was developed especially from the experiments on rock armored permeable slopes with crown walls. It is given as:

$\frac{q T_{0 m}}{L_{0 m}^{2}}=3.2 \times 10^{-5}\left(\frac{H_{s}}{R_{c}}\right)^{3} \frac{H_{s}^{2}}{A_{c} G_{c} \cot \alpha} f($ armor $)$

where; $\mathrm{q}=$ the mean overtopping rate, $\mathrm{H}_{\mathrm{s}}=$ significant wave height, $\mathrm{T}_{0 \mathrm{~m}}=$ mean wave period, $\mathrm{L}_{0 \mathrm{~m}}=$ deep water wave length corresponding to $\mathrm{T}_{0 \mathrm{~m}}$, cot $\alpha=$ structure slope, $\mathrm{R}_{\mathrm{c}}=$ Crown wall freeboard, $A_{c}=$ Armor crest freeboard, $G_{c}=$ armor crest berm width, $f$ (armor) = armor unit factor. Although Pedersen also used cube and dolos units in the experiments, since the majority of the tests have been performed by rock armored slopes, a value of $\mathrm{f}$ (armor type) $=1$ (Pedersen, 1996).

The formula is re-written in terms of common non-dimensional overtopping rate $\mathrm{Q}^{*}$ for the comparative study. This-re-written form is given below:

$Q^{*}=\frac{q}{\sqrt{g H_{s}^{3}}}=3.2 \times 10^{-5}\left(\frac{H_{s}^{1 / 2}}{R_{c}}\right)^{3} \frac{g^{3 / 2} H_{s}^{2} T^{3}}{4 \pi^{2} A_{c} G_{c} \cot \alpha}$

As it can be seen in Eq. (3), Pedersen (1996) states that the nondimensional overtopping rate is inversely proportional to the armor crest freeboard $\mathrm{A}_{\mathrm{c}}$. As $\mathrm{A}_{\mathrm{c}}$ increases wave overtopping decreases linearly. Although Eq. (2) is old, cited in the literature many times (USACE, 2007; Verhaeghe, 2005; Molines and Medina, 2015b) and Pedersen's experiments are covered in CLASH database, predictions have not been included in a recent comparison study (Jafari and Etemad-Shahidi, 2012). The reason may be that it is conservative for small overtopping amounts (Verhaeghe, 2005; USACE, 2007).

Coeveld et al. (2006) studied the influence of crown wall geometry and location on wave overtopping of ruble mound breakwaters with a permeable core. Crown walls of varying height, position and shape (with and without parapet or 'nose') were applied in 2D physical model tests. As a result of the study, they introduced a reduction factor on wave overtopping, $Q^{\prime}$, i.e. the ratio of overtopping rate with and without a crown wall. It is given as: 


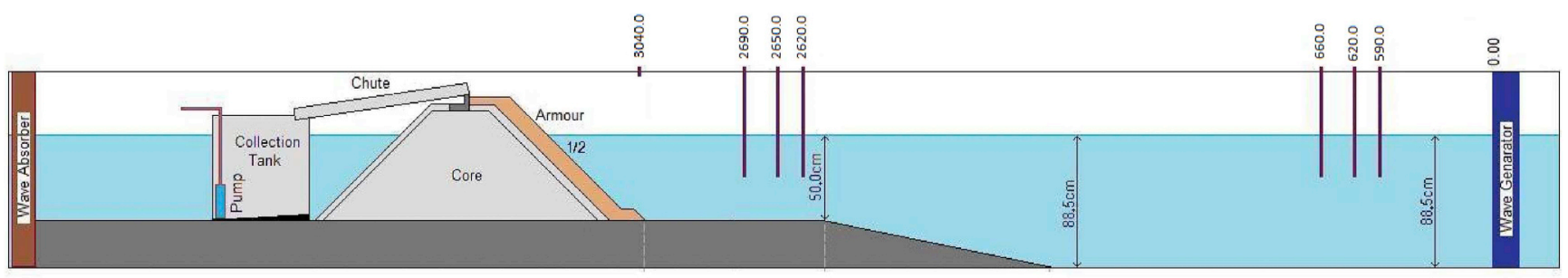

Fig. 2. Experimental Set-up (not in scale).

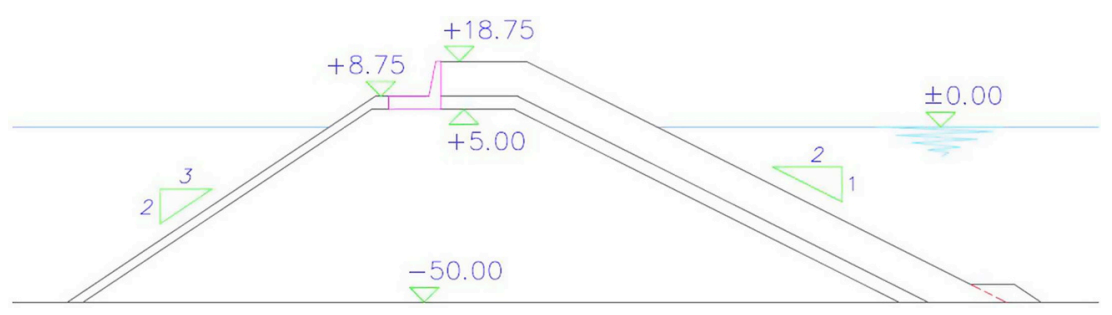

Fig. 3. An example cross-section of the model, $A_{c}=R_{c}=18.75 \mathrm{~cm}$ (units in $\mathrm{cm}$ ).

Table 2

Weight, nominal diameter Dn, armor layer thickness, coefficient $\mathrm{k}_{\Delta}$, porosity p and package density $\Phi$ of armor stone.

\begin{tabular}{|c|c|c|c|c|c|c|}
\hline \multirow[t]{2}{*}{ Armor Unit } & Weight, $W_{50}$ & $\mathrm{Dn}_{50}$ & Armor Layer & \multirow[t]{2}{*}{ thickness factor, $\mathrm{k} \Delta$} & \multirow[t]{2}{*}{ Armor Porosity, $\mathrm{p}$} & \multirow[t]{2}{*}{ Packing Density, $\Phi$} \\
\hline & $(\mathrm{kg})$ & $(\mathrm{m})$ & Thickness (m) & & & \\
\hline Rock & 0.500 & 0.057 & 0.113 & 0.990 & 0.369 & 1.249 \\
\hline
\end{tabular}

Table 3

$\mathrm{D}_{\mathrm{n} 50}, \mathrm{~W}_{50}$ and $\mathrm{Dn}_{85} / \mathrm{Dn}_{15}$ ratios for Filter and Core Materials used in the Experiments.

\begin{tabular}{llll}
\hline Layer & $\mathrm{Dn}_{50}(\mathrm{~m})$ & $\mathrm{Dn}_{85} / \mathrm{Dn}_{15}$ & $\mathrm{~W}_{50}(\mathrm{~g})$ \\
\hline filter layer & 0.018 & 1.19 & 17.00 \\
core layer & 0.010 & 5.00 & 2.69 \\
\hline
\end{tabular}

Table 4

Experiment Cases. An overview of the applied values of the parameters in the experiments is also presented in Table 5 below.

\begin{tabular}{|c|c|c|c|c|c|c|}
\hline \multicolumn{7}{|c|}{ Series $1\left(A_{c}=R_{c}\right)$} \\
\hline $\operatorname{Ac}(\mathrm{m})$ & 0.1375 & 0.1625 & 0.1875 & 0.2125 & 0.2375 & \\
\hline \#of tests & 10 & 10 & 10 & 10 & 10 & $\Sigma=50$ \\
\hline \multicolumn{7}{|c|}{ Series $2\left(R_{c}=0.1875 m\right)$} \\
\hline $\mathrm{Ac} / \mathrm{Rc}$ & 0.73 & 0.87 & 1.00 & 1.13 & 1.27 & \\
\hline \# of tests & 10 & 10 & 10 & 10 & 10 & $\Sigma=50$ \\
\hline \multicolumn{7}{|c|}{ Additional cases $\left(A_{c}=0.1875 m\right)$} \\
\hline $\mathrm{Ac} / \mathrm{Rc}$ & & 1.13 & 0.87 & & & \\
\hline \#of tests & & 10 & 10 & & & $\Sigma=20$ \\
\hline
\end{tabular}

$Q^{\prime}=1.55 \exp \left(-4 \frac{R_{c}-A_{c}}{H_{m 0}}-0.4 \frac{G_{c}}{H_{m 0}}-2 \frac{N_{L}}{H_{m 0}}\right)$

where; $\mathrm{N}_{\mathrm{L}}$ is the length of the parapet (nose) of recurved wall.

Reduction factor in Eq. (4) consists of reductions due to the relative difference between the crown wall and the armor crest freeboards, the armor crest width and the shape of the crown wall. Eq. (4) gives that the reduction in overtopping rate increases as $R_{c}-A_{c}$ difference increases. But when $A_{c}>R_{c}$, formula gives no reduction because $Q^{\prime}>1$. It means that the formula can only explain the reduction if $R_{c}>A_{c}$.

Although it is not a formula, another method based on artificial neural networks to predict the wave overtopping on the permeable
Table 5

Applied values of the parameters in the experiments.

\begin{tabular}{ll}
\hline Parameter & Value \\
\hline Water depth at toe $(\mathrm{m})$ & 0.50 \\
Structure slope & $1 / 2$ \\
Wave Height, $\mathrm{H}_{\mathrm{m} 0}(\mathrm{~m})$ & $0.085-0.17$ \\
Wave Period, $\mathrm{T}_{\mathrm{m}-1,0}(\mathrm{~s})$ & $1.29-2.12$ \\
Crest Width, $\mathrm{G}_{\mathrm{c}}(\mathrm{m})$ & 0.22 \\
Dimensionless Crest Freeboard, $\mathrm{R}_{\mathrm{c}} / \mathrm{H}_{\mathrm{m} 0}$ & $0.9-2.8$ \\
Dimensionless Armor Crest Freeboard, $\mathrm{A}_{\mathrm{c}} / \mathrm{R}_{\mathrm{c}}$ & $0,73-1.27$ \\
Irribaren No & $2.4-3.1$ \\
Total no. of tests & 120
\end{tabular}

mound breakwaters is CLASH Neural Network. Details of the methodology are described in Van Gent et al. (2007). It is an open source online model (http://nn-overtopping.deltares.nl/) and it is possible to calculate mean wave overtopping rate by entering 15 wave and structural input parameters for almost any type of coastal structure covering permeable mound breakwaters. Even one of the structural parameter is the armor crest freeboard $A_{c}$, it is stated that the neural network tool actually takes the maximum of $A_{c}$ and $R_{c}$ to calculate the overtopping rate like EurOtop formula (EurOtop, 2016).

Smolka et al. (2009) conducted small-scale tests of double-layer cube armors and single and double-layer Cubipod armors (Molines and Medina, 2015a). $A_{c} / R_{c}$.ratio is between 0.70 and $1.00,0.4-0.65$ and 0.58-0.80 for cube, cubipod (1 layer) and cubipod (2 layers), respectively. Then they proposed an overtopping prediction formula including the crest freeboard $A_{c}$. It is given in Eq. (5).

$Q^{*}=\frac{q}{\sqrt{g H_{m 0}^{3}}}=0.2 \exp \left(0.53 I r_{p}-3.27 \frac{A_{c}}{R_{c}}-2.16 \frac{R_{c}}{H_{m 0}} \frac{1}{\gamma_{f}}\right)$

Where; $\operatorname{Ir}_{\mathrm{p}}=\mathrm{T}_{\mathrm{p}} / \cot \alpha\left[2 \pi \mathrm{H}_{\mathrm{m} 0} / \mathrm{g}\right] 0.5, \quad \gamma_{\mathrm{f}}$ [cube ] $=0.50, \gamma_{\mathrm{f}}$ [Cubipod, $1 \mathrm{~L}]=0.46$, and $\gamma \mathrm{f}$ [Cubipod 2L] $=0.44$. Eq. (5) shows that Smolka et al. (2009) used $A_{c} / R_{c}$ ratio to include the effect of armor crest freeboard on the wave overtopping. 


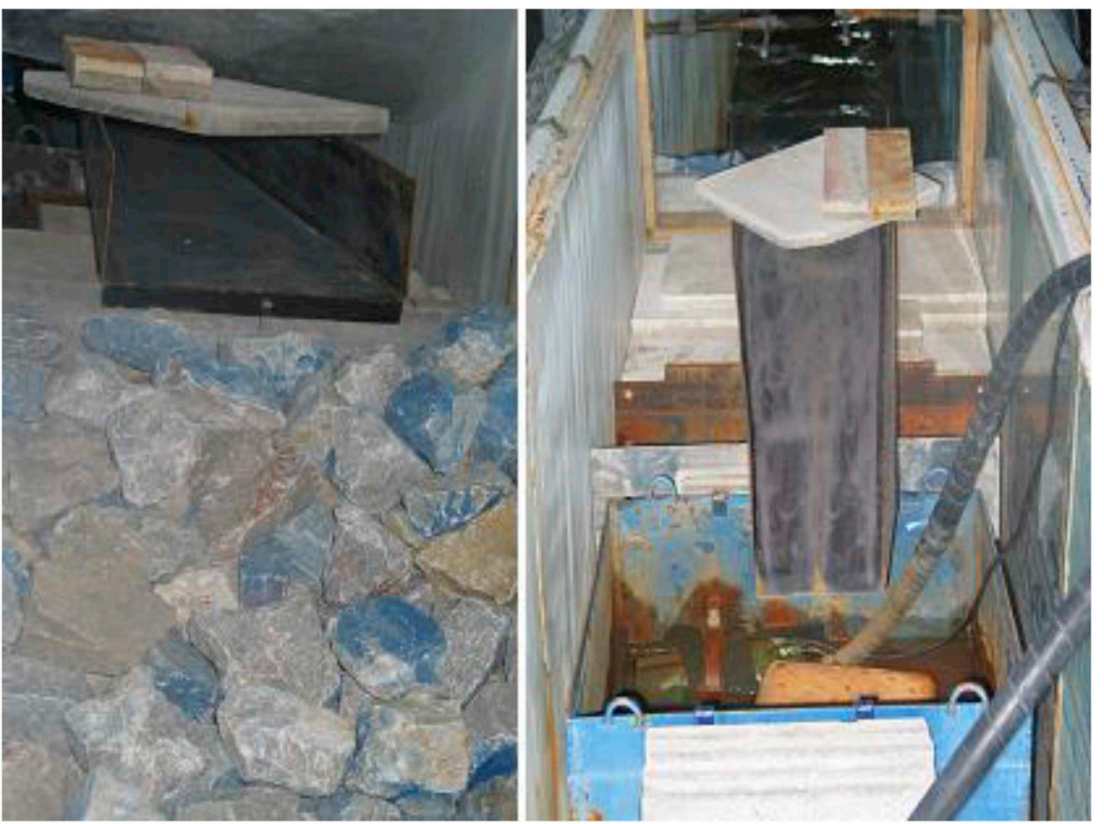

Fig. 4. Overtopping measuring system.

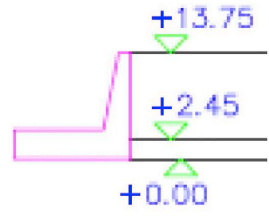

Case1

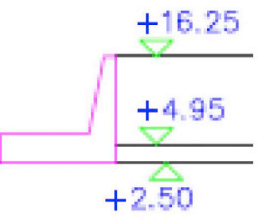

Case2

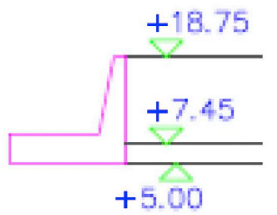

Case3

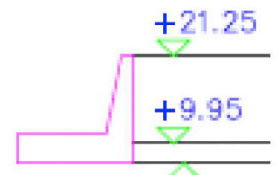

$+7.50$

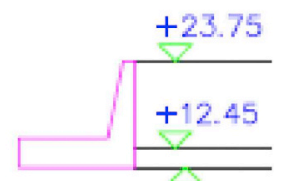

$+10.00$

Fig. 5. Experiment cases in the first series $\left(A_{c}=R_{c}\right.$ and units are in cm).

A new formula is developed for conventional mound breakwaters with crown walls by Molines and Medina (2015b). Based on CLASH Neural Network prediction method and using CLASH database, an explicit formula was developed. The new formula explicitly includes six explanatory dimensionless variables and one of them is relative armor crest freeboard, $A_{c} / R_{c}$. It is given as:

$Q^{*}=\frac{q}{\sqrt{g H_{m 0}^{3}}}=\exp \left(\lambda_{2} \lambda_{3} \lambda_{4} \lambda_{5} \lambda_{6}\left[-1.6-2.6 \frac{R_{c}}{H_{m 0}} \frac{1}{\gamma_{f} \gamma_{\beta}}\right]\right.$

where;

$$
\begin{aligned}
& \lambda_{2}=1.2+0.05\left(\operatorname{Ir} * \sqrt{R_{c} / H_{m 0}}\right) \\
& \lambda_{3}=1+2 \exp \left(-35 * R_{c} / h\right) \\
& \lambda_{4}=\max \left[0.95 ;\left(0.85+0.13 * G_{c} / H_{m 0}\right)\right] \\
& \lambda_{5}=0.85+0.15 * A_{c} / R_{c} \\
& \lambda_{6}=\max \left[1.0 ; 1.2-0.5 R_{c} / h\right] \text { (if there is no toe, it is zero. ) }
\end{aligned}
$$

$I r=$ Irribaren number $=\frac{\tan \alpha}{\sqrt{H_{m 0} / L_{m-1,0}}}$

$\mathrm{H}_{\mathrm{m} 0}=$ Spectral wave height, $\mathrm{L}_{\mathrm{m}-1,0}=$ deep water wave length corresponding to $\mathrm{T}_{\mathrm{m}-1}, \tan \alpha=$ structure slope

From Eq. (6), it can be seen that as $A_{c} / R_{c}$ ratio increases, wave overtopping decreases exponentially.

The application range of Eqs. (1), (2) and (6) are given in Table 1
(EurOtop, 2016, Pedersen, 1996, Molines and Medina, 2015b).

\subsection{This study}

Literature survey shows that there is not any experiment conducted specifically to investigate the effect of armor crest freeboard relative to crown wall freeboard on overtopping by testing all $A_{c}>R_{c}, A_{c}<R_{c}$ and $A_{c}=R_{c}$ cases for simple armored slopes with a crown wall. Moreover, there are few formulas and a neural network tool including the armor crest freeboard $A_{c}$ directly or indirectly to predict the wave overtopping, but the effect of armor crest freeboard on the overtopping is not conclusive in those formulas and tools as it is explained in Section 1.1. In this study, for the first time, a series of hydraulic model experiments are conducted to investigate particularly how the armor crest freeboard is affecting the wave overtopping for simple rubble mound slopes with a crown wall. Rock units are used in the armor layer. In the experiments, the armor crest freeboard, $A_{c}$ and the crown wall freeboard, $R_{c}$ are changed so that wave overtopping data with $A_{c}>R_{c}, A_{c}=R_{c}$, $A_{c}<R_{c}$ conditions are obtained. Then, the experimental results are compared with different prediction formulas and the neural network model. In the next section, details of hydraulic model study are explained. Results of experimental studies, comparison with prediction tools and discussions are given in the third section. Then, a correction factor to cover the influence of armor crest freeboard is presented in the fourth section. Conclusions are provided in the final section of the paper. 


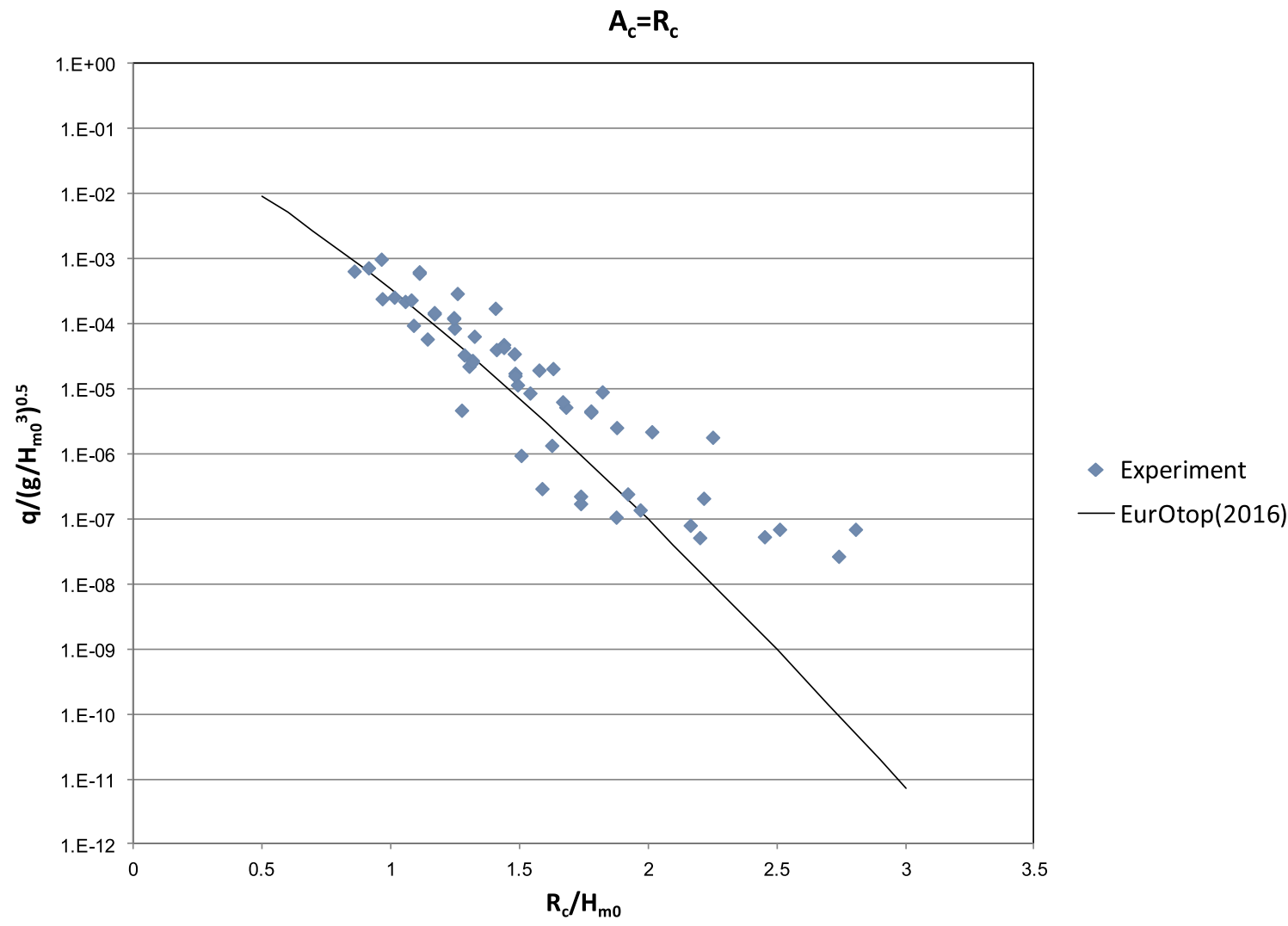

Fig. 6. Results of all wave overtopping measurements for the cases with $A_{c}=R_{c}$.

\section{Hydraulic model experiments}

\subsection{Experimental set-up}

Hydraulic model experiments were conducted in the wave flume $(40 \mathrm{~m} \times 0.6 \mathrm{~m} \times 1.2 \mathrm{~m})$ of Port Hydraulic Research Center, Ministry of Transport in Ankara-Turkey. Models of mound breakwater with 1:2 slope was installed inside the wave flume. The experimental set-up is shown in Fig. 1. While the water depth is $0.885 \mathrm{~m}$ in front of the wave generator, it is $0.50 \mathrm{~m}$ in front of the model. The bottom slope in front of the model is $1 / 20$ as it can be seen in Fig. 2.

The models are consisted of a permeable core, a filter layer and an armor layer with two units of thickness. An example cross-section that $A_{c}=R_{c}=18.75 \mathrm{~cm}$ is given in Fig. 3 . Small rock units are used in the armor layer. Relative mass density, $\Delta=\left(\gamma_{\mathrm{s}}-\gamma_{\mathrm{w}}\right) / \gamma_{\mathrm{w}}$ is equal to 1.69 .

Weight and nominal diameter $D_{n 50}$ of armor stone is given together with the armor layer thickness, layer thickness factor, $\mathrm{k}_{\Delta}$, armor porosity, $\mathrm{p}$, and packing density, $\Phi$ in Table 2 . Layer thickness factor $\mathrm{k}_{\Delta}$ is defined as the ratio of armor layer thickness to two times $D_{n}$. Armor layer thickness was measured at different points of armor layer which can be observed from the glass walls of wave flumes. Packing density, $\Phi$ is given as (Medina et al., 2014):

$\Phi=\mathrm{n} \mathrm{k}_{\Delta}(1-\mathrm{p})$

where; $n$ is the number of layers ( 2 in this case) and $p$ is the armor porosity. The armor porosity was calculated as the ratio of the volume of armor units used along the slope of the armor layer to the whole volume of armor layer along the slope (width of the flume $\mathrm{x}$ length of the slope $\mathrm{x}$ armor layer thickness). The toe and the crest parts were excluded in the porosity calculations.

Table 2 shows that the armor porosity and thickness factors of rocks are in the range given in the previous studies (Pearson et al., 2004; Bruce et al., 2009; Medina et al., 2014).

According to the mass distribution of filter layer stones and sieve analysis of core layer stones $\mathrm{D}_{\mathrm{n} 50}, \mathrm{~W}_{50}$ and $\mathrm{Dn}_{85} / \mathrm{Dn}_{15}$ ratio are given in Table 3. $\mathrm{D}_{\mathrm{n} 50}$ (armor)/ $/ \mathrm{D}_{\mathrm{n} 50}$ (filter) was 3.08. For the core layer, the requirement is that the weight is less than $1 / 50 \mathrm{~W}_{50}$, where $\mathrm{W}$ is the weight of the armor unit (Bruce et al., 2009). $\mathrm{W}_{\text {armor }} / \mathrm{W}_{\text {core }}$ was 185.9 in the experiments.

In the tests, placement of the rocks was irregular without any pattern. Stability of the units was ensured during all overtopping tests. There was no displacement. In order to prevent the sliding, the toe was supported by a concrete plate.

\subsection{Wave generation}

The wave generator inside the wave flume was installed by JICA (Japan International Cooperation Agency) through a technical cooperation between Turkish and Japanese Governments. It is a piston type generator which is capable of generating regular and irregular waves. During the experiments, an irregular wave train with almost 1000 waves (changing between 989 and 1185 waves) was generated in each test. For the calculation of wave time series to be sent to the wave generator by an electrical signal, software produced by Mitsui Company and PARI (Port and Airport Research Institute) from Japan is used. It is possible to calculate required time series by setting up the water level, wave characteristics, target spectrum and random numbers for phase angles in this software. Target spectrum shape was BretschniderMitsuyasu spectrum in the experiments. Bretschneider-Mitsuyasu spectrum is based on the proposal by Bretschneider with adjustment of the coefficients by Mitsuyasu (Goda, 2010) and it is given in Eq. (8).

$S(f)=0.257 H_{1 / 3}^{2} T_{1 / 3}^{-4} f^{-5} \exp \left(-1.03\left(T_{1 / 3} f\right)^{-4}\right)$

Bretschnider-Mitsuyasu spectrum is developed for fully wind waves like PM spectra. In fact, PM spectra expression can be converted into Bretschneider-Mitsuyasu spectra formula by introducing the wave height and period because the functional dependence with respect to frequency is the same (Goda, 2010). The wave generator doesn't have 

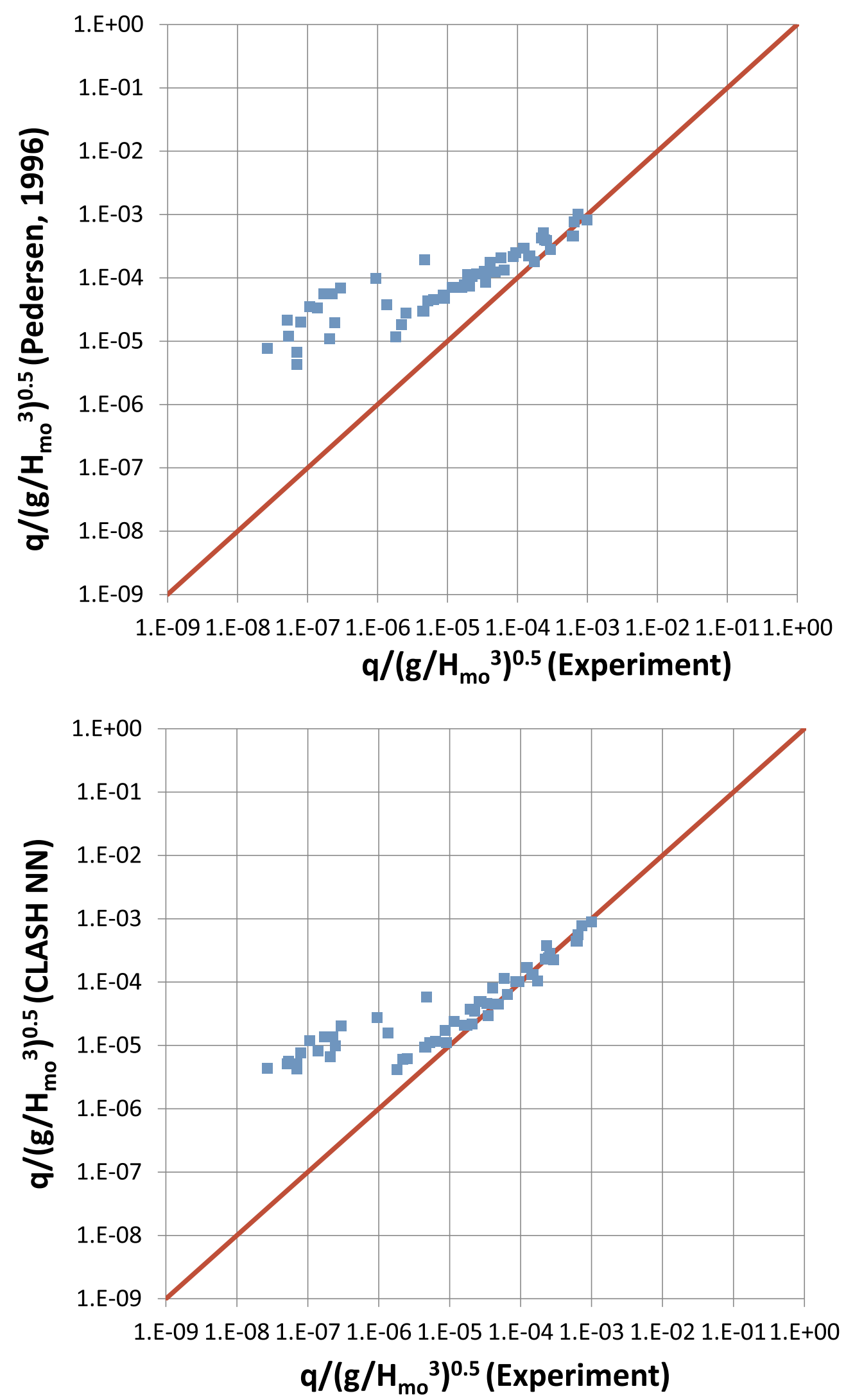

Fig. 7. Comparison of the measured and the predicted overtopping rates by the formulas and CLASH NN for $A_{c}=R_{c}$ condition. 


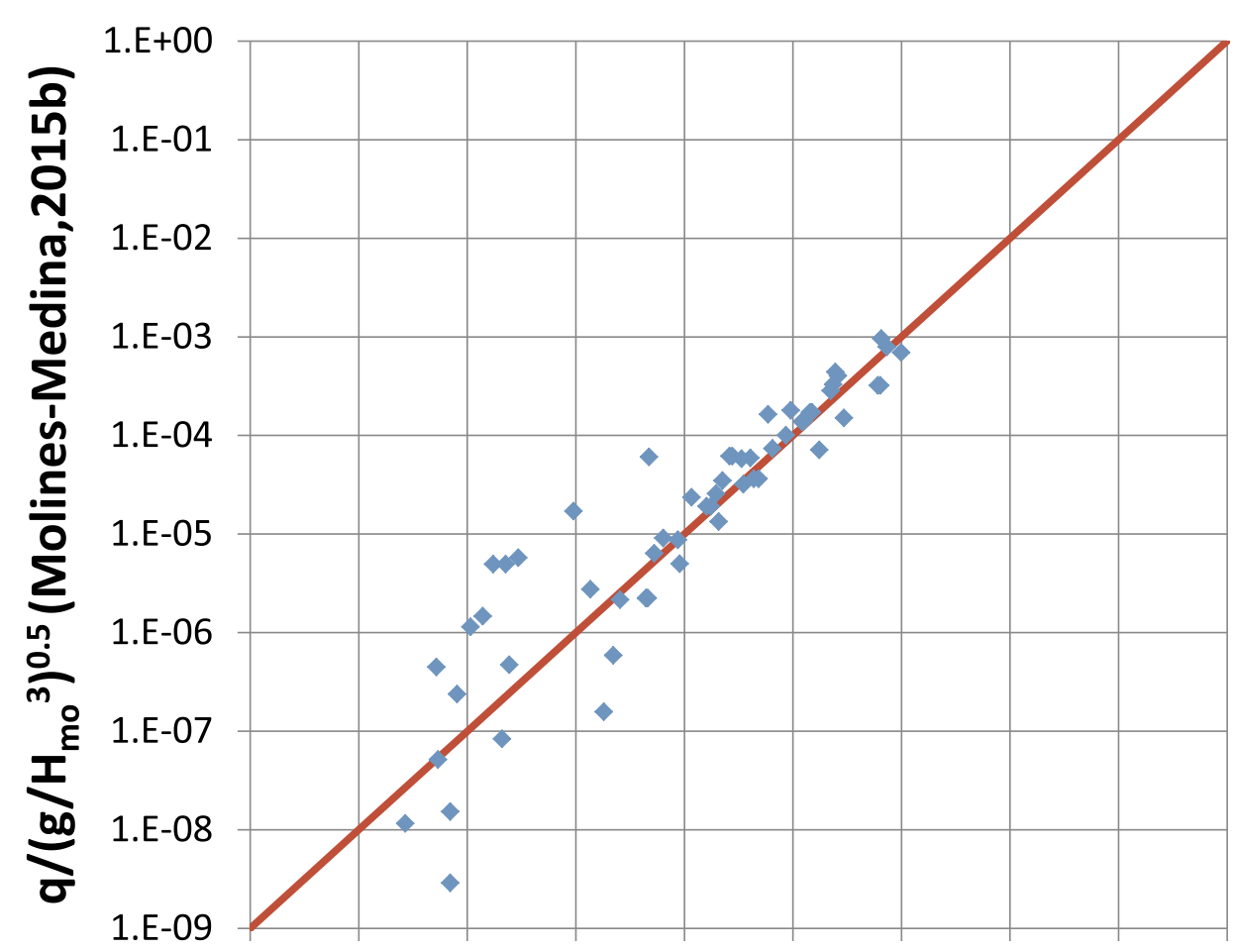

1.E-09 1.E-08 1.E-07 1.E-06 1.E-05 1.E-04 1.E-03 1.E-02 1.E-011.E+00 $\mathrm{q} /\left(\mathrm{g} / \mathrm{H}_{\mathrm{mo}}{ }^{3}\right)^{0.5}$ (Experiment)

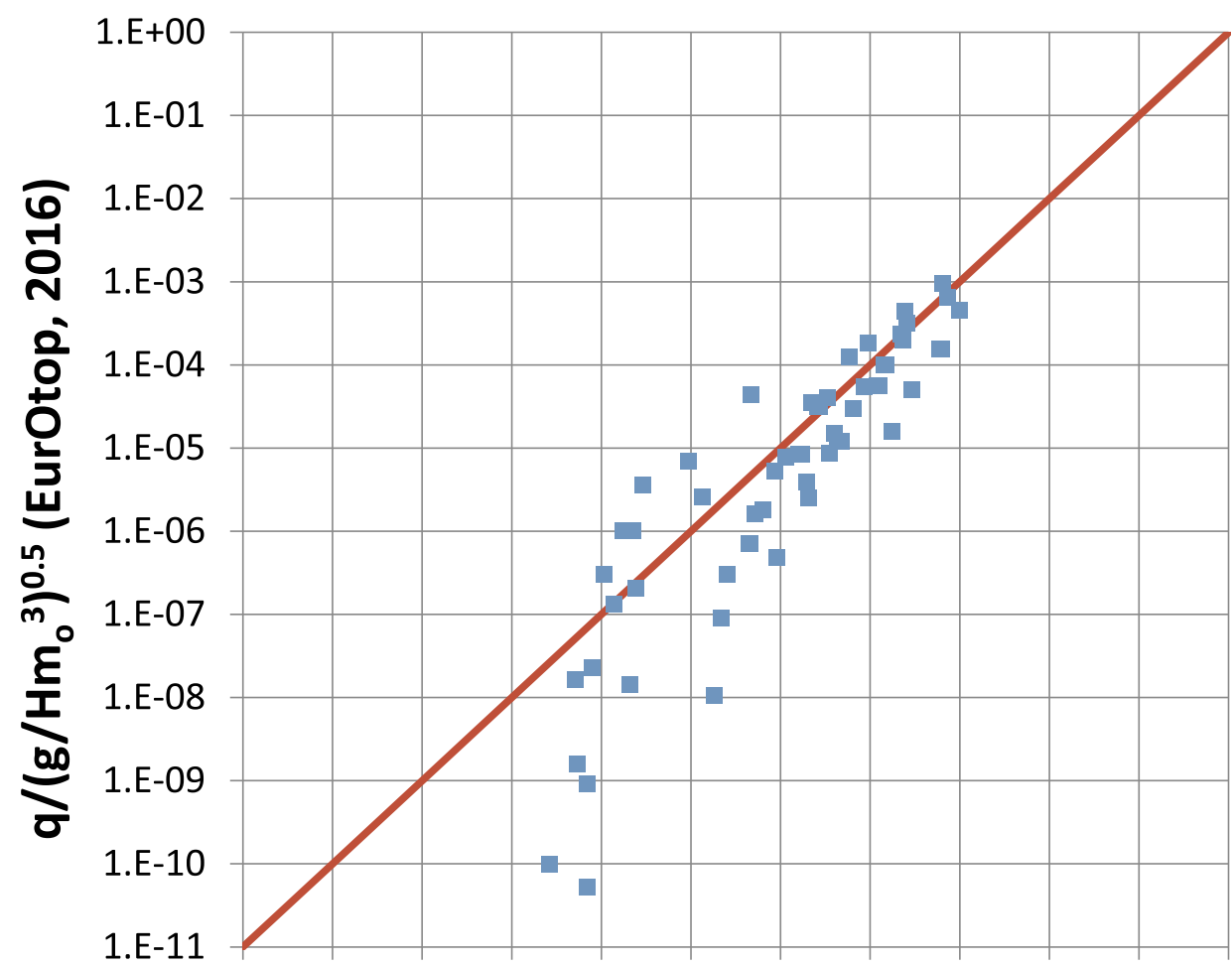

1.E-11.E-10.E-09.E-08.E-01.E-06.E-05.E-04.E-03.E-01.E-01.E+00 $\mathrm{q} /\left(\mathrm{g} / \mathrm{Hm}_{\mathrm{o}}{ }^{3}\right)^{0.5}$ (Experiment)

Fig. 7. (continued) 


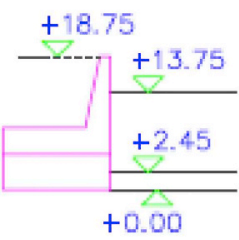

Case6

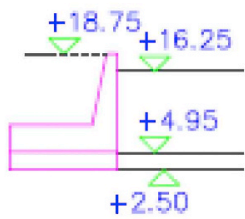

Case7

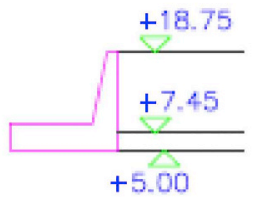

Case8

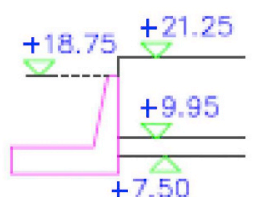

Case9

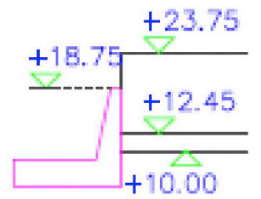

Case10

Fig. 8. Experiment cases in the second series $\left(A_{c} \neq R_{c}\right.$ and units are in $\left.\mathrm{cm}\right)$.

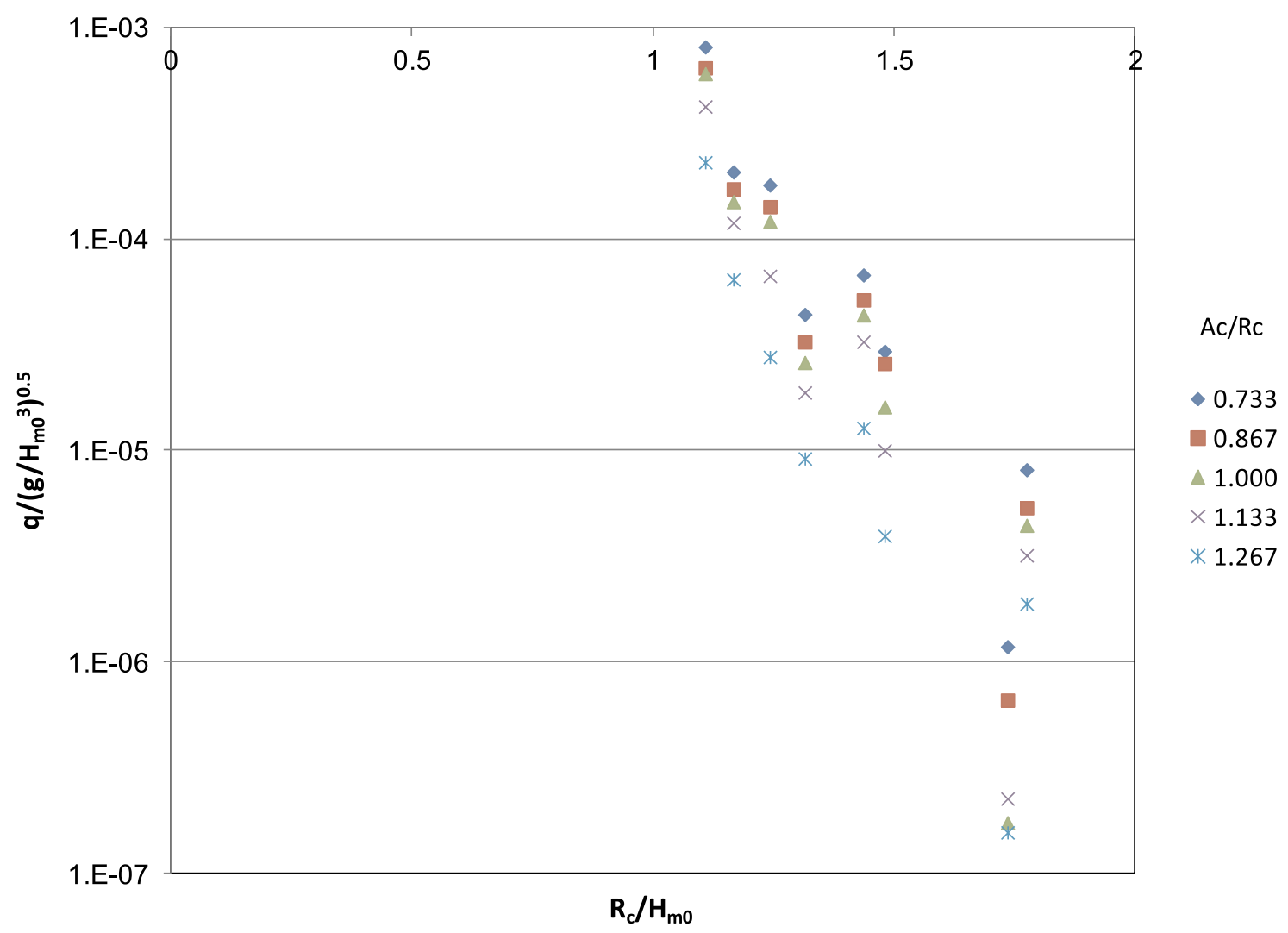

Fig. 9. Effect of armor crest freeboard $A_{c}$ on wave overtopping for constant crown wall freeboard, $R_{c}$.

an active wave absorption system.

\subsection{Wave recording and analysis}

After the generation of waves started, waves were recorded with 16,384 data. A sampling rate was chosen according to the mean wave period, $\mathrm{T}_{\mathrm{m}}$ generated in the tests. The sampling rates during the tests were between $7.24 \mathrm{~Hz}$ and $12.82 \mathrm{~Hz}$. Since there was a reflection in the flume due to model, it was compulsory to separate incident waves from reflected waves. Incident wave energy spectrum was obtained by using the separation method introduced by Goda and Suzuki (1976). It is a two points method and very sensitive to the distance between the gauges, dl. Because the wave resolution is effective in the range outside the condition of the gauge spacing (dl) being the even integer of half wave length (Goda and Suzuki, 1976). A divergence happens at $\mathrm{k} \mathrm{dl}=\mathrm{n}$ $\pi$ ( $\mathrm{k}$ is the wave number $=2 \pi / \mathrm{L}$ ). In this study, any suitable pairs of three wave gauges separated with a distance of $0.3 \mathrm{~m}$ and $0.4 \mathrm{~m}$ are used to extend the effective resolution frequency range. Therefore it could be possible to separate the waves with a whole period range used in the tests. The wave profile in front of the wave generator were also measured by another three wave gauges. After getting incident wave energy spectrum, spectral wave height $\mathrm{H}_{\mathrm{m} 0}$, and periods, $\mathrm{T}_{\mathrm{m}-1,0}$ and $\mathrm{T}_{02}$ used in the comparison study are calculated as defined in Eq. (9).

$H_{m 0}=4.004 \sqrt{m_{0}}$
$T_{m-1,0}=m_{0} / m_{-1}$
$T_{02}=\sqrt{m_{0} / m_{2}}$

where; $\mathrm{m}_{\mathrm{n}}=\mathrm{n}^{\prime}$ th moment of spectral density.

Spectral wave height and the periods are calculated both in front of the generator $(\mathrm{d}=0.885 \mathrm{~m})$ and at the toe of the structure $(\mathrm{d}=0.50 \mathrm{~m})$.

Wave gauges are capacitance type gauges and they were calibrated before the wave record was started every experiment day. Measurement stability of $50 \mathrm{~cm}$ length wave gauges is within $\pm 1 \% / 24 \mathrm{~h}$ and \pm $0.5 \% / 10{ }^{\circ} \mathrm{C}$.

\subsection{Experiment cases}

Experimental study was carried out by two series of experiments. In the first one, there were five cases and the armor crest freeboard $A_{c}$ was changed in each case. The crown wall freeboard was equal to the armor 
crest freeboard $\left(A_{c}=R_{c}\right)$ in these five cases. In the second experimental series, $A_{c}$ value was changed in five cases by keeping $R_{c}$ constant. Additional two cases with constant $A_{c}$ were conducted to compare the effect of $R_{c}$ and $A_{c}$ on the wave overtopping and to check the effect of $A_{c}$ for $R_{c}$ values different than those used in the second experimental series. There were 10 tests in each case and each test had different wave height and period corresponding to steepness of 0.025 and 0.04 . These ten tests were repeated in each case. In order to analyze the influence of the $A_{c}$ independently of the armor crest berm width, $G_{c}$, it was kept constant in all the cases $\left(G_{c} \cong 3 D_{n 50}\right)$. Experiment cases for each series are summarized in Table 4. As it can be noticed in Table 4, the number of cases was 12 and the total number of tests was 120 in the experiments.
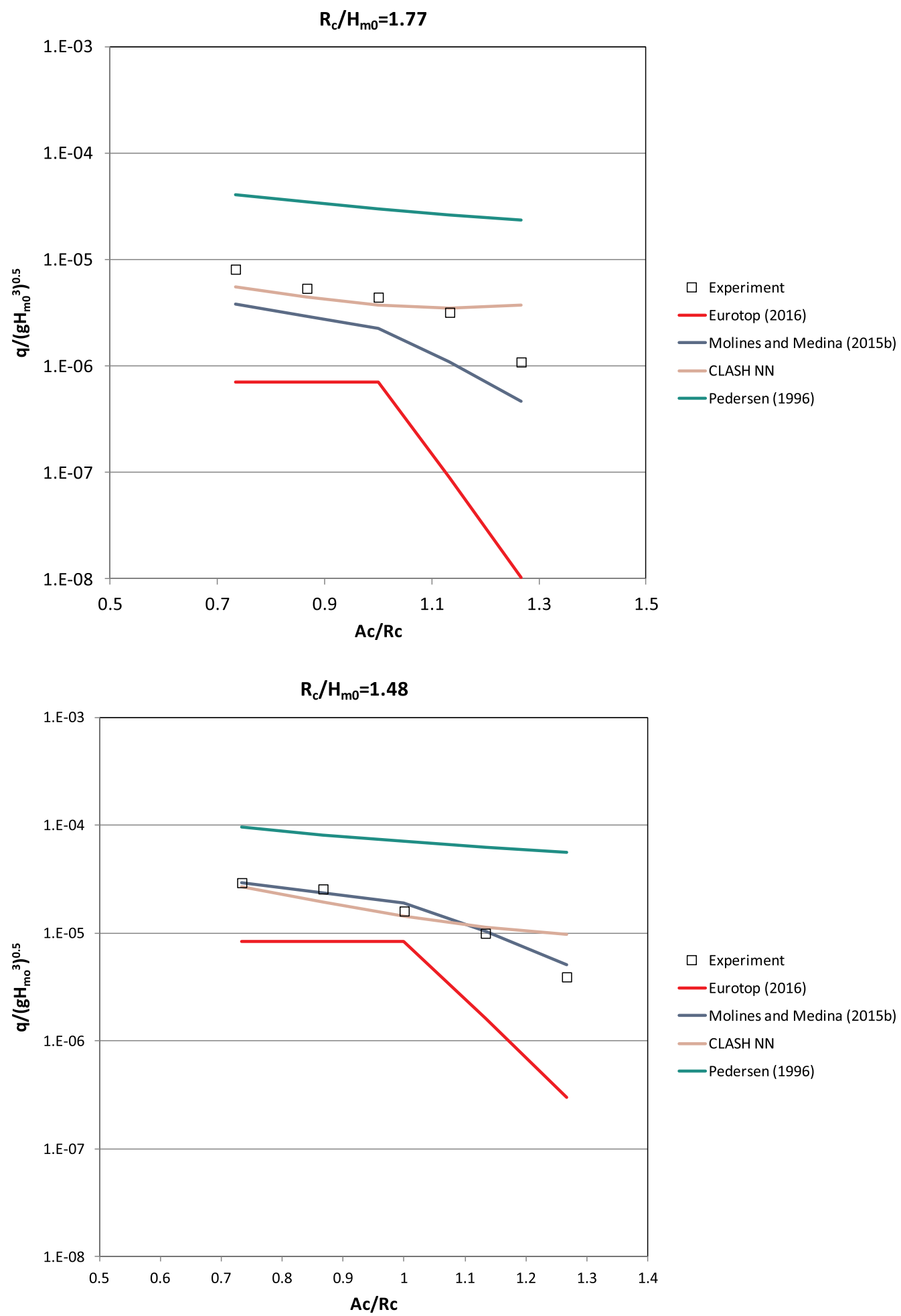

Fig. 10. Change in the overtopping rate as the armor crest freeboard increases (experiment and predictions). 


\subsection{Wave overtopping measurement}

Wave overtopping is given as a discharge but it is different from a steady discharge (Van der Meer et al., 2010). Only the waves reaching the crest of the structure will overtop, and bring a volume of water in a short time. However, since it is difficult to measure the volumes of the individual wave overtopping in a laboratory, the majority of published overtopping research considers mean overtopping discharges $q$, expressed as flow rates per meter of the structure $\left(\mathrm{m}^{3} / \mathrm{s} / \mathrm{m}\right.$ or $\left.1 / \mathrm{s} / \mathrm{m}\right)$.

In this study, amount of wave overtopping was measured by a chute and collection tank. The width of the chute was $0.29 \mathrm{~m}$ and it was installed on the crest of the crown wall in the middle of the test section. Overtopped water was collected in a leeside tank through the chute. At the end of each test, collected water was pumped out from the tank and its weight was measured. Then, mean overtopping rate, q, was calculated as $1 / \mathrm{m} / \mathrm{sec}$. Overtopping measuring system is presented in Fig. 4.
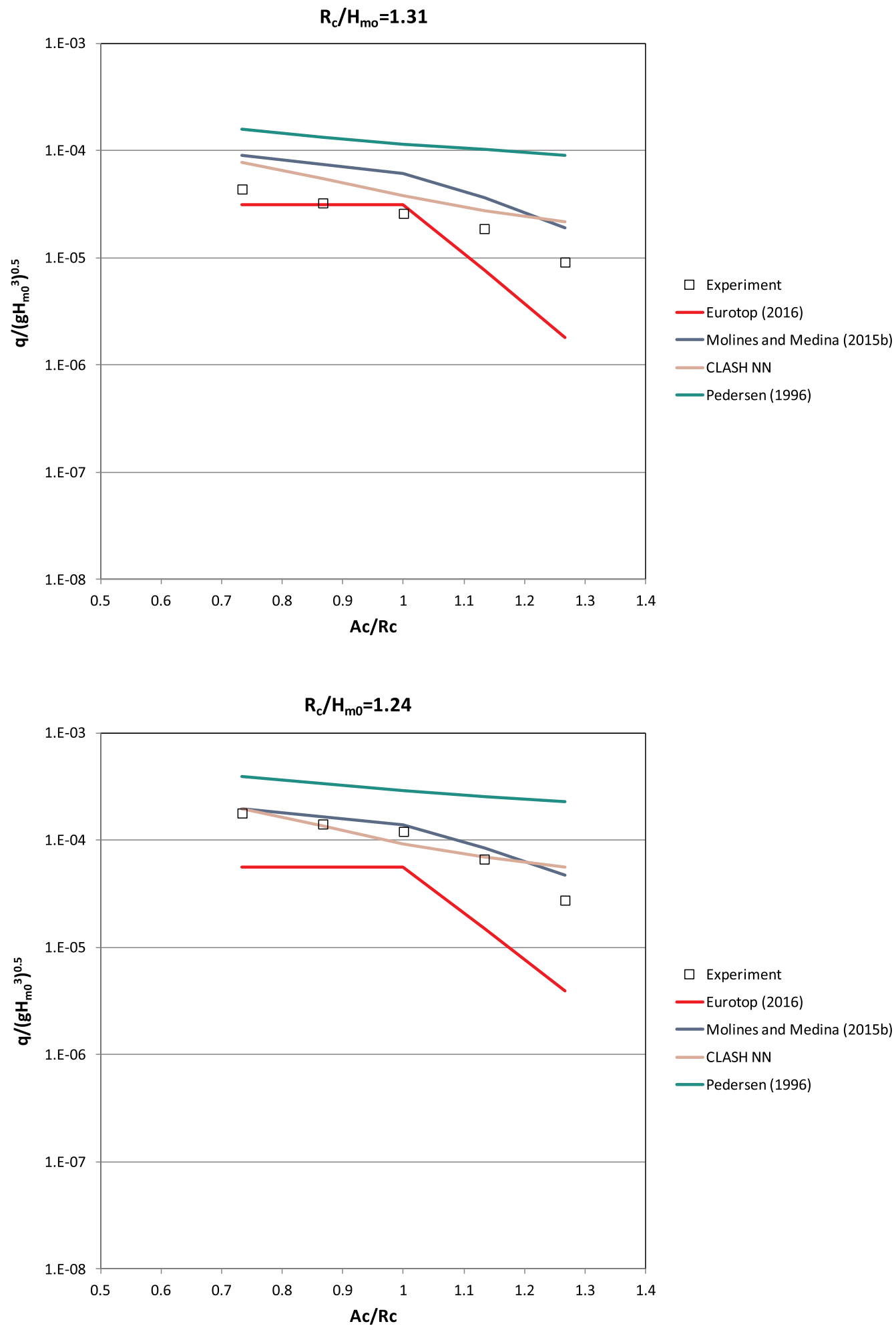

Fig. 10. (continued) 


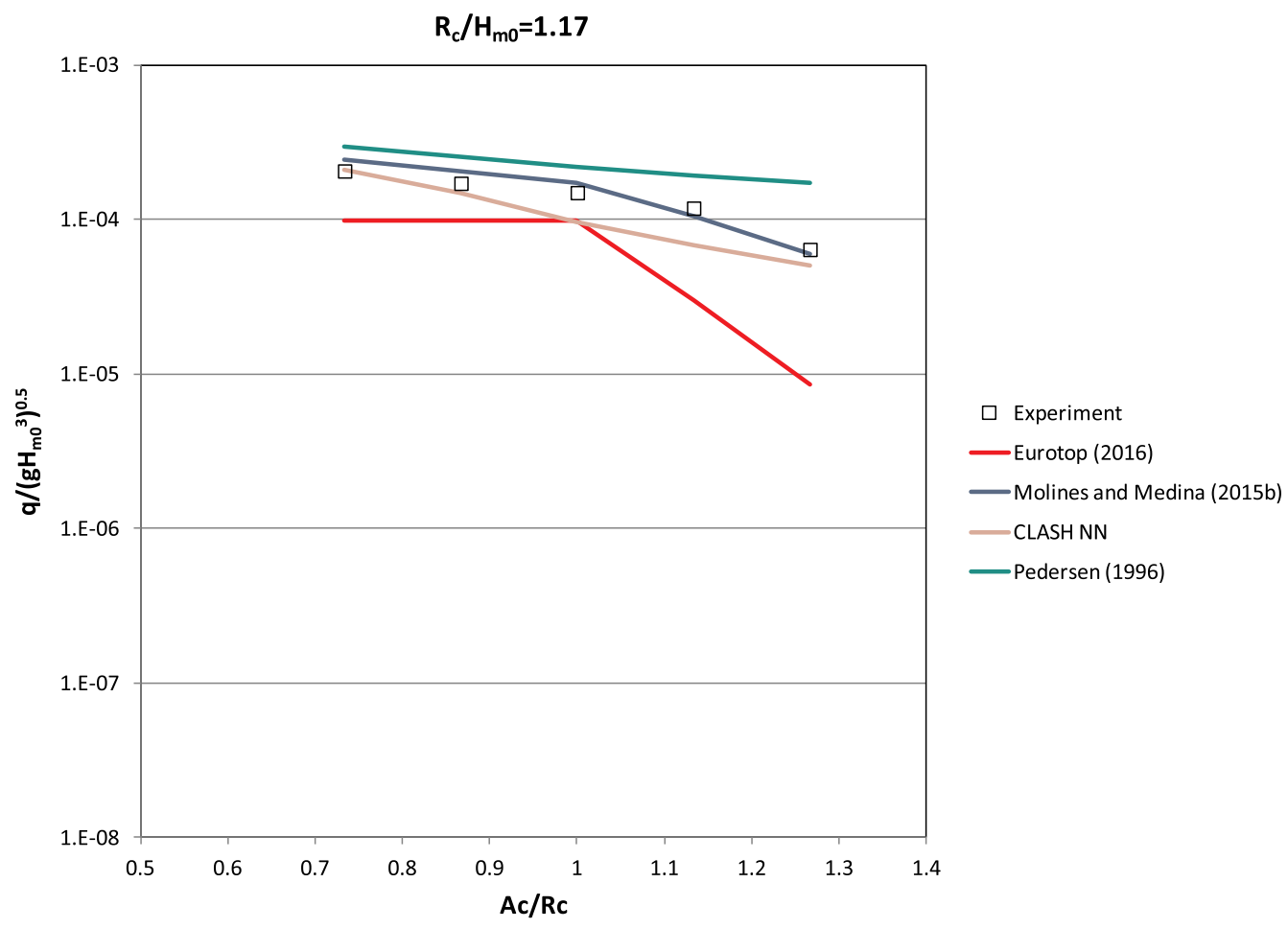

Fig. 10. (continued)

\section{Experimental results}

\subsection{The first series of experiments $\left(A_{c}=R_{c}\right)$}

In the first series of experiments, there were 5 cases in which the armor crest freeboard $A_{c}$ was changed. The crown wall freeboard had the same height as the armor crest freeboard, so $A_{c}=R_{c}$ in these five cases represented in Fig. 5.

The results of all wave overtopping measurements in the five cases with $A_{c}=R_{c}$ are presented by plotting $R_{c} / H_{m 0}$ vs nondimensional overtopping rate, $Q^{*}=\mathrm{q} /\left(\mathrm{gH}_{\mathrm{m} 0}\right)^{0.5}$ in Fig. 6. Q* predictions of EurOtop (2016) given in Eq. (1) with roughness coefficient $\gamma_{\mathrm{f}}=0.4$ and $\mathrm{R}_{\mathrm{sc}}=\mathrm{R}_{\mathrm{c}}=\mathrm{A}_{\mathrm{c}}$ are also plotted on the same figure.

Fig. 6 shows that the wave overtopping is decreasing while $R_{c} / H_{m 0}$ increasing as it is expected. Even the data seems scattered for the very low values of overtopping, EurOtop (2016) may predict the overtopping rate when $A_{c}=R_{c}$.

Measured overtopping rates for $A_{c}=R_{c}$ condition are also compared with the predictions by Pedersen (1996), Molines and Medina (2015b), EurOTop (2016) and CLASH NN. Reduction factors to account the surface roughness and permeability for rock armor units on permeable core are 0.4, 0.48 and 0.49 for EurOtop (2016), Molines and Medina (2015b) and CLASH NN, respectively. Comparison results are presented in Fig. 7.

Fig. 7 shows that Pedersen (1996) overestimates the overtopping rate. There is a very good match between the measured and the predicted overtopping rates by CLASH Neural Network (NN) tool except very low overtopping rate tests since both $\mathrm{NN}$ predictions and experimental measurements are less reliable for $\mathrm{q}<10^{-5}$. Molines and Medina (2015b) and EurOtop (2016) predict the overtopping well in the case of $A_{c}=R_{c}$ but the prediction results seem scattered for low overtopping tests.

\subsection{The second series of experiments (effect of armor crest freeboard, $A_{\mathcal{C}}$ )}

In the second experimental series, the effect of armor crest freeboard was investigated by changing $A_{c}$ value in five cases in which $R_{c}$ was kept constant. $A_{c} / R_{c}$ ratios are $0.73,0.87,1.00,1.13$ and 1.27 in these cases shown in Fig. 8. The given range of $A_{c} / R_{c}$ seems convenient for real applications because as $A_{c} / R_{c}$ decreases, the crown wall freeboard becomes much higher than the armor crest freeboard. It is avoided due to the wave pressure impact on the wall. Beside, much higher $\mathrm{A}_{\mathrm{c}} / \mathrm{R}_{\mathrm{c}}$ value means that armor crest freeboard is too high relative to the crown wall freeboard and then the crown wall will not have any effect on the wave overtopping.

In order to investigate the effect of armor crest freeboard on the wave overtopping, experimental results of different $A_{c} / R_{c}$ cases are compared by plotting $\mathrm{R}_{\mathrm{c}} / \mathrm{H}_{\mathrm{m} 0}$ vs nondimensional overtopping rate, $\mathrm{Q}^{*}=\mathrm{q} /\left(\mathrm{gH}_{\mathrm{mo}}{ }^{3}\right)^{0.5}$. Results are given in Fig. 9.

Fig. 9 indicates that the wave overtopping decreases as the armor crest freeboard increases independent of the crown wall freeboard and other parameters. Change in the overtopping rate due to the increase in the armor crest freeboard is given in Fig. 10 as a plot of $A_{c} / R_{c}$ versus nondimensional overtopping rate, $Q^{*}=\mathrm{q} /\left(\mathrm{gH}_{\mathrm{mo}}\right)^{0.5}$ for different $\mathrm{R}_{\mathrm{c}} /$ $\mathrm{H}_{\mathrm{mo}}$ values. Wave overtopping predictions of Pedersen (1996), Molines and Medina (2015b), EurOTop (2016) and CLASH NN are also plotted in Fig. 10.

It should be noted that EurOtop (2016) given in Eq. (1) does not include armor crest freeboard $\mathrm{A}_{c}$ directly. However, its effect is taken into consideration by using $A_{c}$ instead of $R_{c}$, if $A_{c}>R_{c}$. Otherwise $R_{c}$ is used. Therefore, if $A_{c}<R_{c}$, wave overtopping prediction calculated by EurOtop (2016) does not change as it can be seen in Fig. 10. Because $R_{c}$ is constant in the experiment cases of 6-10. Fig. 10 shows that when $A_{c} /$ $R_{c}<1$, wave overtopping increases gradually as $A_{c}$ decreases and that increase can be predicted by Molines and Medina (2015b) and CLASH 
NN tool. When $A_{c} / R_{c}>1$, wave overtopping decreases rapidly as $A_{c}$ increases. While this rapid decrease is overestimated by EurOtop (2016) as it is indicated in Fig. 10, it is predicted well by Molines and Medina (2015b) and CLASH NN. A linear decrease in the wave overtopping is predicted by Pedersen (1996) due to $A_{c}$ but overtopping rate is overestimated in all cases.

In order to compare the overtopping rate of $A_{c}<R_{c}$ and $A_{c}>R_{c}$ cases (cases 6, 7, 9 and 10) with $A_{c}=R_{c}$ case (case 8), the non-dimensional overtopping rates $Q^{*}$ calculated from the cases 6,7,9 and 10 are divided to $Q^{*}$ of the case $8\left(A_{c}=R_{c}\right)$ under the same wave conditions. $A_{c} / R_{c}$ versus division results of both experiment and the predictions are given in Fig. 11.

Fig. 11 shows that when $A_{c}$ is lower than $R_{c}\left(A_{c} / R_{c}<1\right)$, the wave overtopping increases gradually compared to overtopping rate with $A_{c}=R_{c}$. This gradual increase in wave overtopping rate is ignored by EurOtop (2016). It is overestimated by CLASH NN, but well predicted by Molines and Medina (2015b) and Pedersen (1996). Fig. 11 also indicates that when $A_{c}$ is higher than $R_{c}\left(A_{c} / R_{c}>1\right)$, the wave overtopping decreases as $A_{c}$ increases for the same $R_{c}$. While this reduction in the overtopping is overestimated by EurOtop (2016), it is well predicted by Molines and Medina (2015b).

Figs. 10 and 11 show the change in the wave overtopping due to armor crest freeboard for different $\mathrm{R}_{c} / \mathrm{H}_{\mathrm{m} 0}$ ratios. In order to present the effect of armor crest freeboard on wave overtopping in one plot, Fig. 11 is re-plotted by using the non-dimensional freeboard difference parameter, $\left(A_{c}-R_{c}\right) / H_{m 0}$ instead of $A_{c} / R_{c}$ and it is given in Fig. 12. Fig. 12 shows only the results of the tests with the non-dimensional overtopping rate $>10^{-7}$, because test results may not be reliable for very small overtopping discharges.

Results with circles in Fig. 12 are for $R_{c}=18.75 \mathrm{~cm}$. Overtopping discharge results of additional experiment cases, Case 11 and 12 shown in Fig. 13 are also plotted on the same figure to check the convenience of the non-dimensional freeboard difference parameter, $\left(A_{c}-R_{c}\right) / H_{m 0}$. The non-dimensional overtopping rates, $Q^{*}$ of Case $11\left(R_{c}=16.25 \mathrm{~cm}\right.$ and $\left.A_{c}>R_{c}\right)$ and Case12 $\left(R_{c}=21.25 \mathrm{~cm}\right.$ and $\left.A_{c}<R_{c}\right)$ are divided to $\mathrm{Q}^{*}$ of Case $2\left(\mathrm{R}_{\mathrm{c}}=\mathrm{A}_{\mathrm{c}}=16.25 \mathrm{~cm}\right)$ and Case $4\left(\mathrm{R}_{\mathrm{c}}=\mathrm{A}_{\mathrm{c}}=21.25 \mathrm{~cm}\right)$,

\section{$R_{c} / H_{m 0}=1.77$}

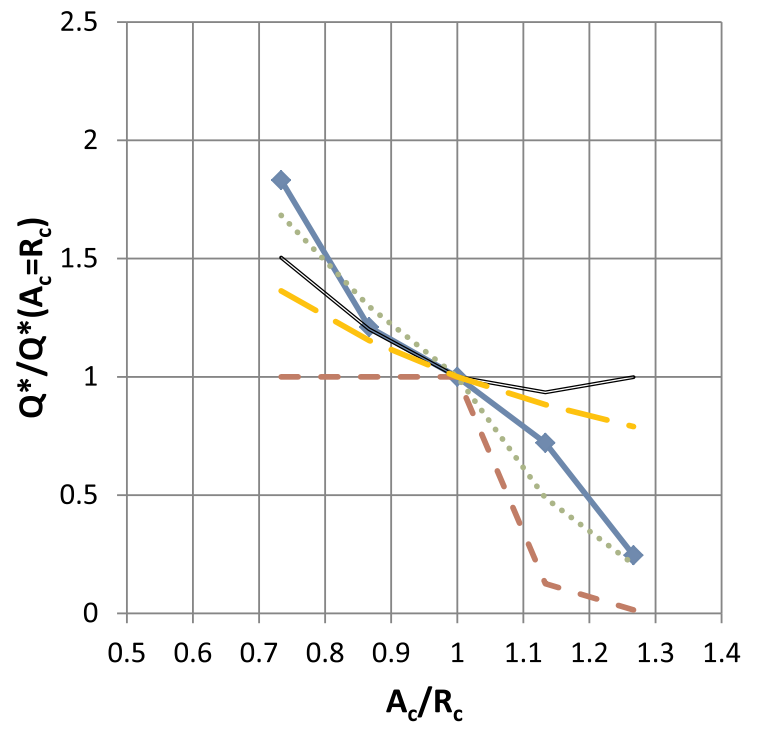

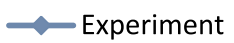

- Eurotop (2016)

Molines and Medina

(2015b)

$\Longrightarrow$ CLASH NN

- Pedersen (1996)

\section{$\mathrm{R}_{\mathrm{c}} / \mathrm{H}_{\mathrm{m} 0}=\mathbf{1 . 4 8}$}

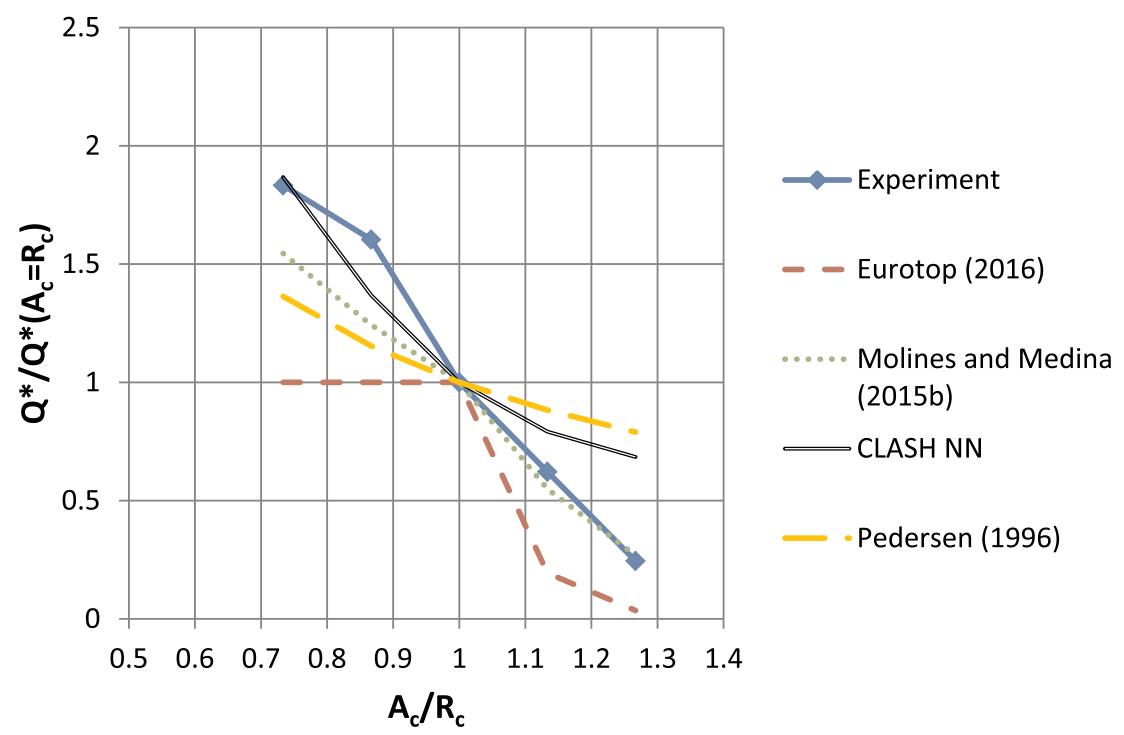

Fig. 11. The reduction in the wave overtopping due to armor crest freeboard for different $R_{c} / H_{m 0}$. 


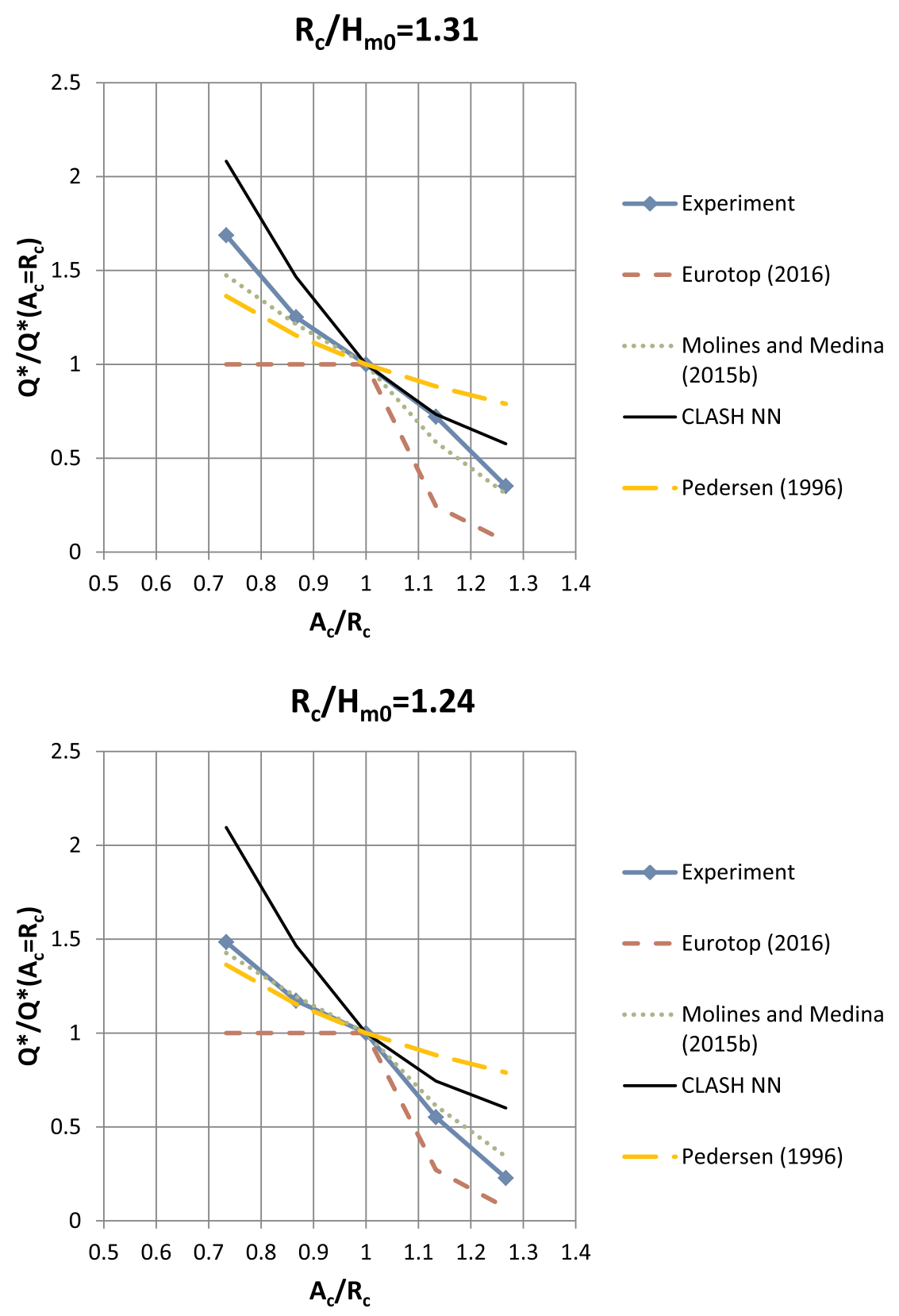

Fig. 11. (continued) 


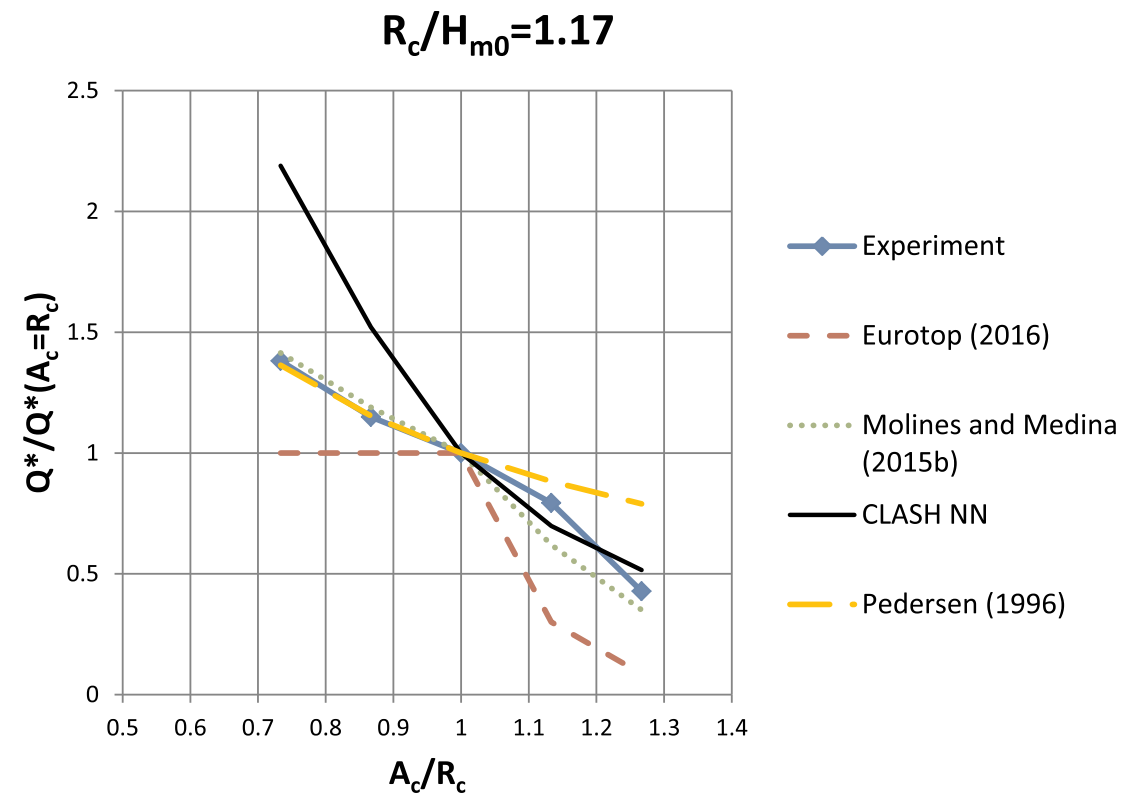

Fig. 11. (continued)

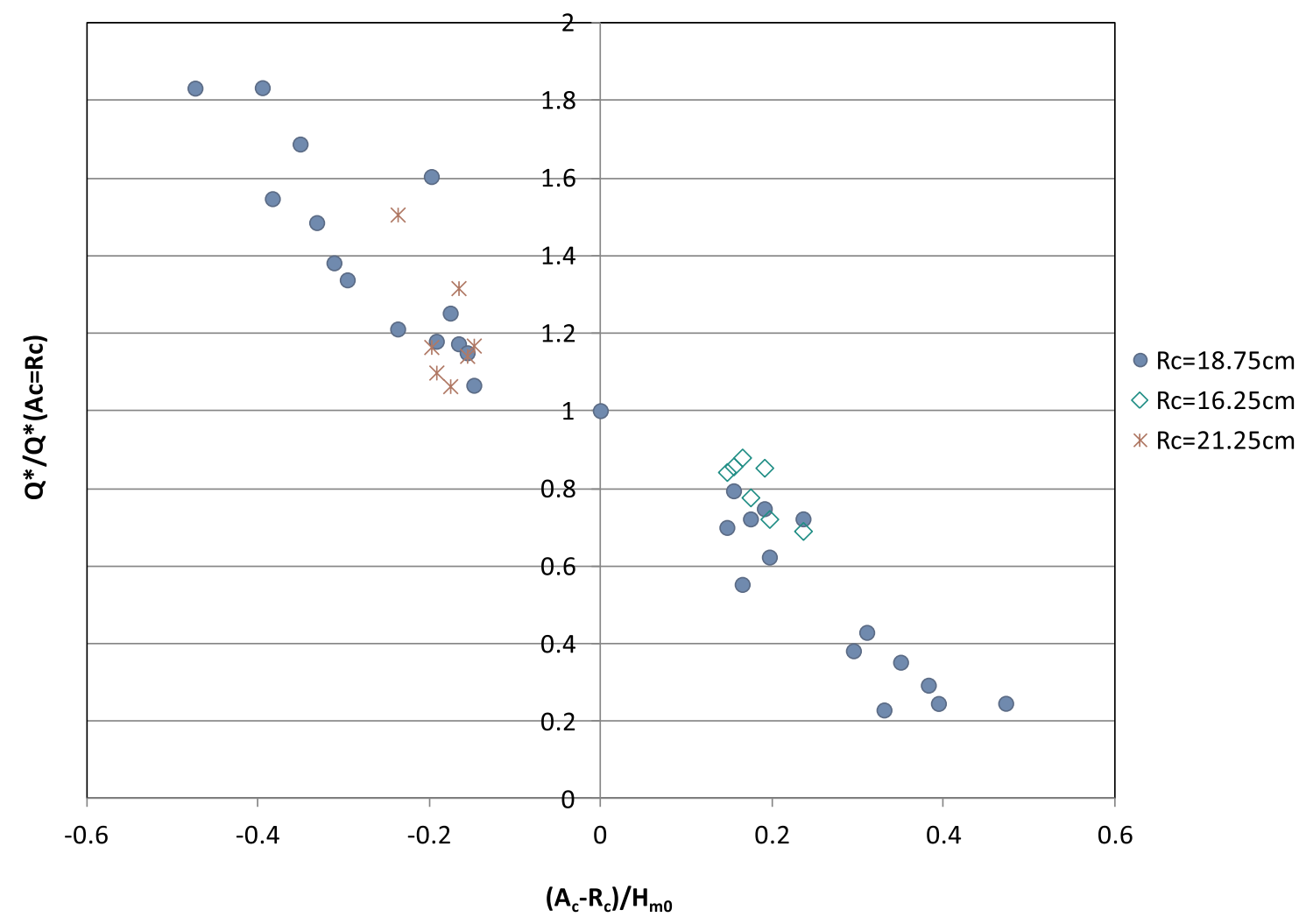

Fig. 12. Change in the wave overtopping due to armor crest freeboard $Q^{*}=q /\left(\mathrm{gH}_{\mathrm{mo}}\right)^{0.5}$. 


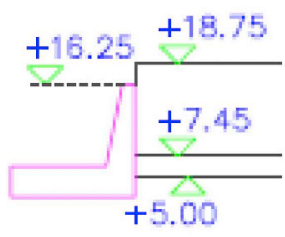

Case11

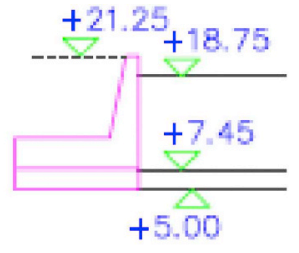

Case12
Fig. 13. Additional cases (units are in $\mathrm{cm}$ ).

respectively under the same wave conditions. Fig. 12 indicates that results of Case 11 and Case 12 are similar to other experimental results with $R_{c}=18.75 \mathrm{~cm}$ for the same value of $\left(A_{c}-R_{c}\right) / H_{m 0}$. Therefore it can be said that $\left(A_{c}-R_{c}\right) / H_{m 0}$ is a convenient parameter to indicate the influence of armor crest freeboard on the wave overtopping.

\subsection{The comparison of wave overtopping reduction due to increase in $R_{c}$} and increase in $A_{c}$

It has already been shown that wave overtopping is reduced as $A_{c}$ increases. Is this reduction in the wave overtopping equal to the overtopping reduction due to increase in $R_{c}$ ? To answer this question, firstly, overtopping discharge results were obtained for $R_{c}>A_{c}$ condition by using the experimental cases 6,7 and $12 . A_{c} / R_{c}$ ratios were $0.7,0.8$ and 0.9 in these cases. In order to investigate the reduction in the wave overtopping due to $R_{c}$, the non-dimensional overtopping rates, $Q^{*}$ of Cases 6, 7 and 12 are divided to $Q *$ of cases 1,2 and 3 in which $R_{c}=A_{c}$, respectively under the same wave conditions. Then, the division results and the corresponding non-dimensional freeboard difference, $\left(\mathrm{R}_{\mathrm{c}-\mathrm{A}} \mathrm{A}_{\mathrm{c}}\right) /$ $\mathrm{H}_{\mathrm{mo}}$ values are plotted in Fig. 14. In Fig. 14, experimental results of Aminti and Franco (1988) and Pedersen (1996) and the predictions of Coeveld et al. (2006) are also presented. The experimental results of Aminti and Franco (1988) and Pedersen (1996) are obtained from CLASH database. It should be noted that results in Fig. 14 show the reduction in the wave overtopping due to increase in crown wall freeboard, $\mathrm{R}_{\mathrm{c}}$ since $\mathrm{A}_{\mathrm{c}}$ was kept constant in the comparison.

Fig. 14 indicates that the current and previous experiments with $R_{c}>A_{c}$ cases constitute a wider range of $\left(R_{c-} A_{c}\right) / H_{m 0}$. Moreover, the reduction in the wave overtopping due to the crown wall freeboard $R_{c}$ can be predicted well by Coeveld et al. (2006).

After then, in order to compare the wave overtopping reduction due to increase in $A_{c}$ and due to increase in $R_{c}$, experimental results for the cases with $A_{c}>R_{c}$ (case 9, 10 and 11) are plotted together with the reduction results of Coeveld et al. (2006) and shown in Fig. 15. The non-dimensional freeboard difference, $\left(A_{c}-R_{c}\right) / H_{m 0}$ in the $x$ axis is given as absolute value in Fig. 15 because the experiment cases show the reduction results due to increase in $A_{c}\left(\left(A_{c}-R_{c}\right) / H_{m 0}>0\right)$ but Coeveld et al. (2006) gives the reduction due to increase in $R_{c}\left(\left(A_{c}-R_{c}\right) /\right.$ $\mathrm{H}_{\mathrm{m} 0}<0$ ).

As it can be seen in Fig. 15, the overtopping reductions in the experiment cases are lower than Coeveld et al. (2006). It means that the overtopping reduction due to $A_{c}$ is lower than the reduction due to $R_{c}$ for the same non-dimensional freeboard $\left(A_{c}-R_{c}\right) / H_{m 0}$. The reason may be the porosity of armor crest. Some of the overtopped waves can penetrate through the armor crest so; these penetrations may decrease the reduction in the wave overtopping. Therefore, to take the maximum of $\mathrm{R}_{\mathrm{c}}$ and $\mathrm{A}_{\mathrm{c}}$ for the structure crest freeboard in the prediction formulas as it is in EurOtop (2016) may give underestimated overtopping results, if $A_{c}>R_{c}$.

\section{Overtopping rate correction factor due to $A_{c}$}

As it is given in Section 3, experimental results show that armor crest freeboard affects the wave overtopping rate. While the armor crest freeboard lower than the crown wall freeboard gives larger overtopping, higher armor crest freeboard reduces the overtopping compared to the overtopping in the case of $A_{c}=R_{c}$. However, this reduction is not the same as the reduction due to the increase in the crown wall freeboard. Therefore, a new correction factor is proposed to describe the influence of merely armor crest freeboard by using experimental results given in Fig. 12. This factor represented by $C_{A c}$ is the ratio of overtopping rate with $A_{c} \neq R_{c}$ to the overtopping rate with $A_{c}=R_{c}$. The correction factor $C_{A c}$ is given in Eq. (10).

$C_{A_{c}}= \begin{cases}\exp \left(-1.205 \frac{(A c-R c)}{H m o}\right) & \text { if } \frac{A c}{R c}<1 \\ \exp \left(-2.733 \frac{(A c-R c)}{H m o}\right) & \text { if } \frac{A c}{R c}>1\end{cases}$

It should be noted that when $A_{c}=R_{c}, C_{A c}=1$.

In Fig. 16, the correction factor $\mathrm{C}_{\mathrm{Ac}}$ calculated by the measured wave overtopping rates are given as well as the ones predicted with the formulae in Eq. (10). The correlation coefficient is 0.908 .

EurOtop (2016) given in Eq. (1), provides a very simple and robust formula to predict wave overtopping rate for simple armored slopes. The formula does not include, for example, the armor crest berm width but, a reduction factor on overtopping rate given by Besley, (1999) is used to cover the influence of armor crest berm width. First the wave overtopping discharge is calculated for a simple slope, with a crest width up to 3Dn. Then reduction factor of Besley is applied if the berm width is wider than $3 \mathrm{Dn}$. Similar methodology is suggested here if $A_{c}$ is not equal to $R_{c}$ to cover the effect of armor crest freeboard in EurOtop (2016). Firstly, the wave overtopping discharge is calculated by using the crown wall freeboard $R_{c}$ for $R_{s c}$ given in Eq. (1). Then the correction factor given in Eq. (10) is applied. Overtopping discharge results of experiment cases in which $A_{c}$ is not equal to $R_{c}$ are compared to EurOtop (2016) predictions with and without the correction factor, $\mathrm{C}_{\mathrm{Ac}}$ (Eq. (9)). Comparison results are presented in Fig. 17.

Fig. 17 shows that overtopping discharge results of corrected EurOtop (2016) by the factor $\mathrm{C}_{\mathrm{Ac}}$ are better correlated to experimental discharge results compared to the formula without correction.

\section{Conclusions}

In this study, for the first time, a series of hydraulic model experiments are conducted to investigate specifically the influence of armor crest freeboard relative to crown wall freeboard on overtopping by testing all $A_{c}>R_{c}, A_{c}<R_{c}$ and $A_{c}=R_{c}$ cases for simple rubble mound slopes with a crown wall. In the first series of experiments, there were 5 cases in which armor crest freeboard had the same height as the crown wall freeboard, so $A_{c}=R_{c}$. In the second experimental series, the effect of armor crest freeboard was investigated by changing $A_{c}$ value in five cases. In order to analyze the influence of $A_{c}$ independent of the crown wall freeboard, $R_{c}$ and the armor crest berm, $G_{c}$, crest parameters $R_{c}$ and $G_{c}$ were kept constant in all the cases. Additional two cases were conducted to observe the effect of $A_{c}$ on the wave overtopping for different $R_{c}$ values. Here are the conclusions of this study: 


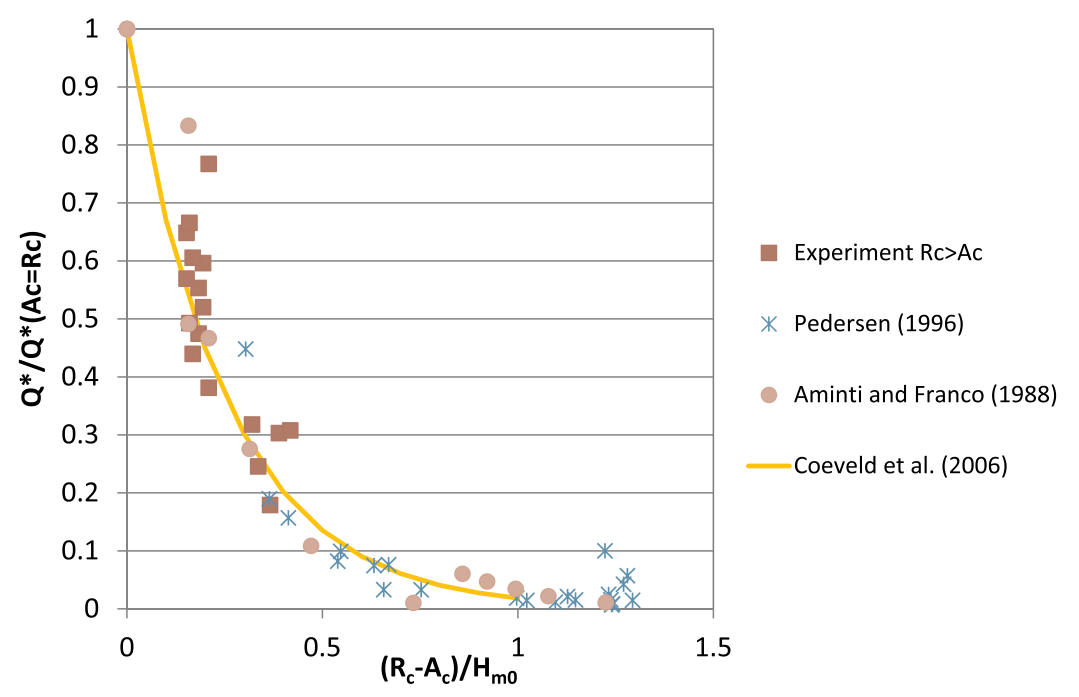

Fig. 14. The reduction in the wave overtopping due to crown wall freeboard, $R_{c}$.

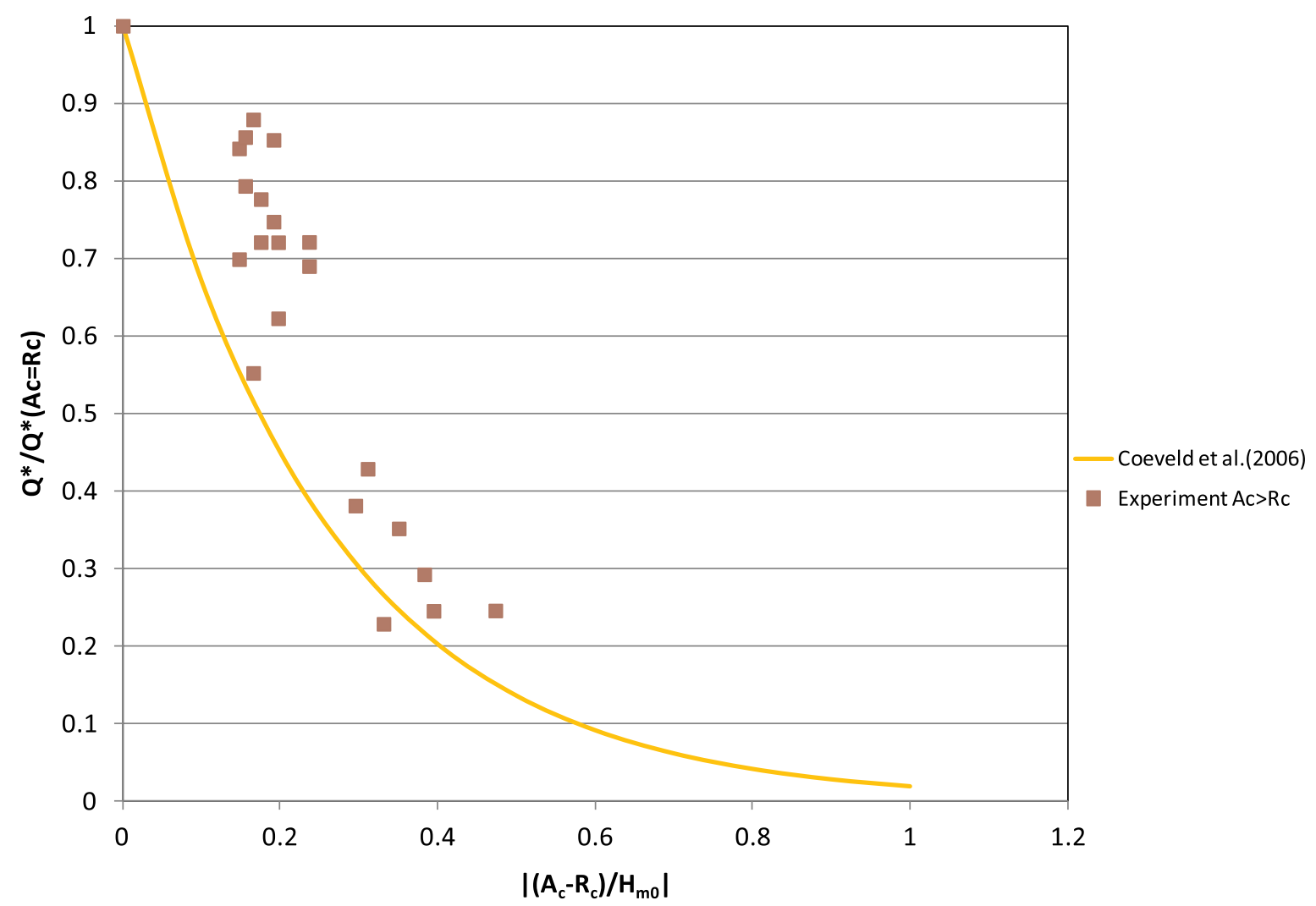

Fig. 15. The Comparison of wave overtopping reduction due to increase in Rc (by Coeveld et al., 2006) and increase in $A_{c}$ (by the experimental results). 


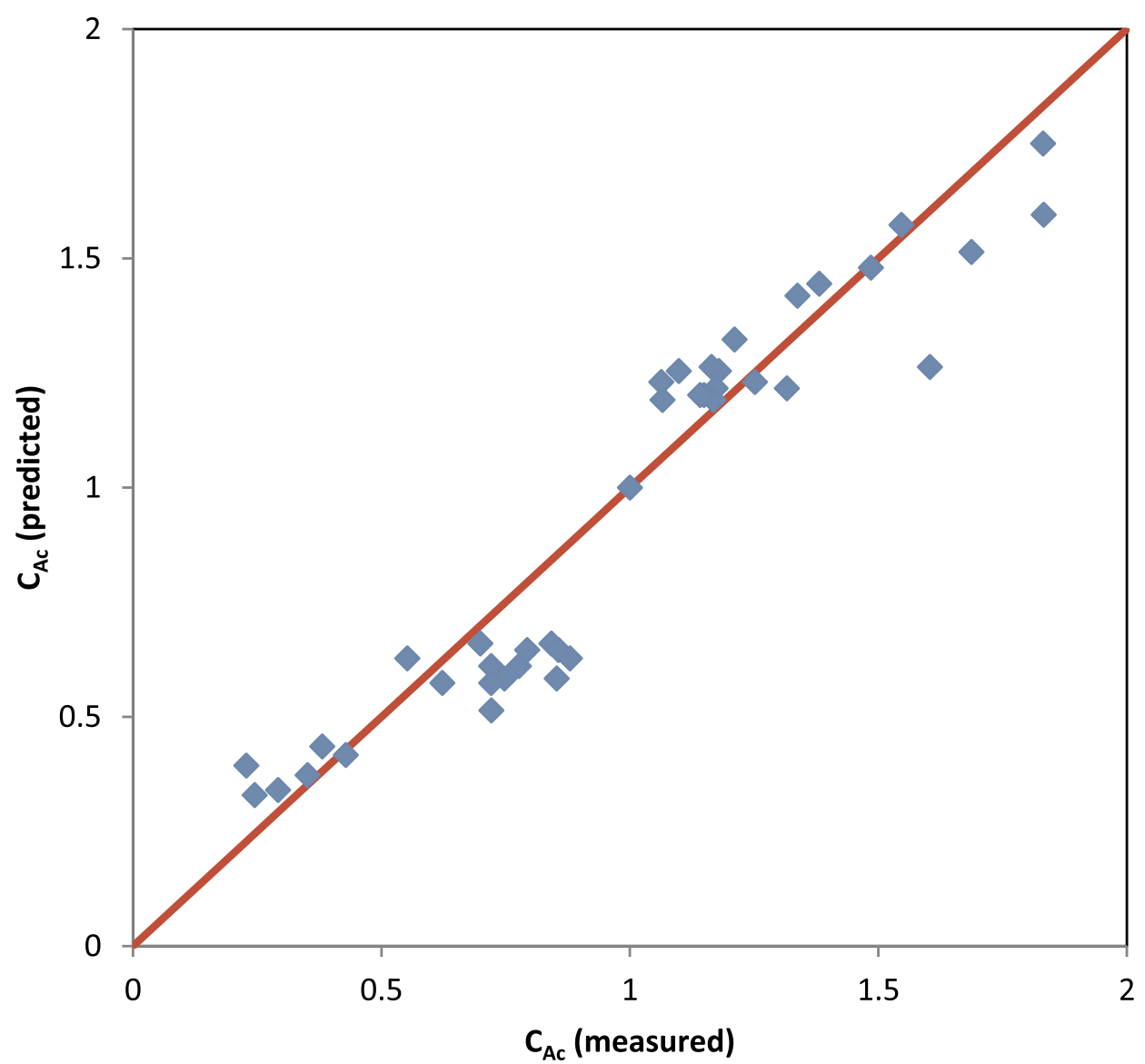

Fig. 16. Correction factor $C_{A c}$ calculated by the measured wave overtopping rates and the predicted with the formulae in Eq. (10).

Measured overtopping rates for $\mathrm{A}_{\mathrm{c}}=\mathrm{R}_{\mathrm{c}}$ condition are compared with the predictions by Pedersen (1996), Molines and Medina (2015b), EurOTop (2016) and CLASH NN. Comparison study shows that Pedersen (1996) overestimates the overtopping rate. There is a very good match between the measured and the predicted overtopping rates by CLASH Neural Network (NN) tool except very low overtopping rate cases since both the measurements and the NN prediction are less reliable (indicative) for $\mathrm{q}<10^{-5}$. Molines and Medina (2015b) and EurOtop (2016) predict overtopping well in the case of $A_{c}=R_{c}$ but the prediction results seem scattered for the low overtopping tests.

Experiments conducted particularly to investigate the effect of armor crest freeboard indicate that the armor crest freeboard relative to the crown wall freeboard affects the wave overtopping rate. While the armor crest freeboard lower than the crown wall freeboard is giving larger overtopping, higher armor crest freeboard reduces the overtopping compared to the overtopping in the case of $A_{c}=R_{c}$. However, this reduction is less than the reduction caused by the increase in the crown wall freeboard. The reason may be the porosity of the armor crest. Some of the overtopped waves can penetrate through the armor crest so; these penetrations may decrease the reduction in the wave overtopping. Since only the rock units are used in the armor layer, the effect of the surface roughness and porosity could not be tested. It can be investigated in a future study.

A new correction factor is proposed to describe the influence of armor crest freeboard by using experimental results. This factor represented by $C_{A c}$ is the ratio of wave overtopping rate with $A_{c} \neq R_{c}$ to the wave overtopping rate with $A_{c}=R_{c}$. The correction factor $C_{A c}$ is given in Eq. (10).

EurOtop (2016) provides a very simple and robust formula to predict wave overtopping rate for simple armored slopes. However, it does not include armor crest freeboard $A_{c}$ directly. The effect of $A_{c}$ is taken into consideration by using $A_{c}$ instead of $R_{c}$, if $A_{c}>R_{c}$. Otherwise $R_{c}$ is used. However, comparison study show that the approach of EurOtop (2016) explained above causes underestimated overtopping rates for both $A_{c}<R_{c}$ and $A_{c}>R_{c}$ cases compared to $A_{c}=R_{c}$ cases. Therefore, the correction factor $\mathrm{C}_{\mathrm{Ac}}$ may be applied to cover the influence of armor crest freeboard in EurOtop (2016). Firstly, the wave overtopping rate is calculated by the original formula using the crown wall freeboard $R_{c}$ for the structure crest, $R_{s c}$. Then, if $A_{c}$ is not equal to $R_{c}$, correction factor given in Eq. (10) may be applied. A verification study shows that overtopping rate predictions of EurOtop (2016) with the correction factor $\mathrm{C}_{\mathrm{Ac}}$, are better correlated to measured rate results compared to the predictions of the original formula.

The effect of armor crest freeboard on the wave overtopping can be predicted well by Molines and Medina (2015b). CLASH NN results follow the similar trends for the reduction and the increase in the wave overtopping due to $A_{c}$, but it can be modified by using the new experimental results as a future study.

It should be noted that these conclusions are valid for the given range of the parameters in the experiment. 

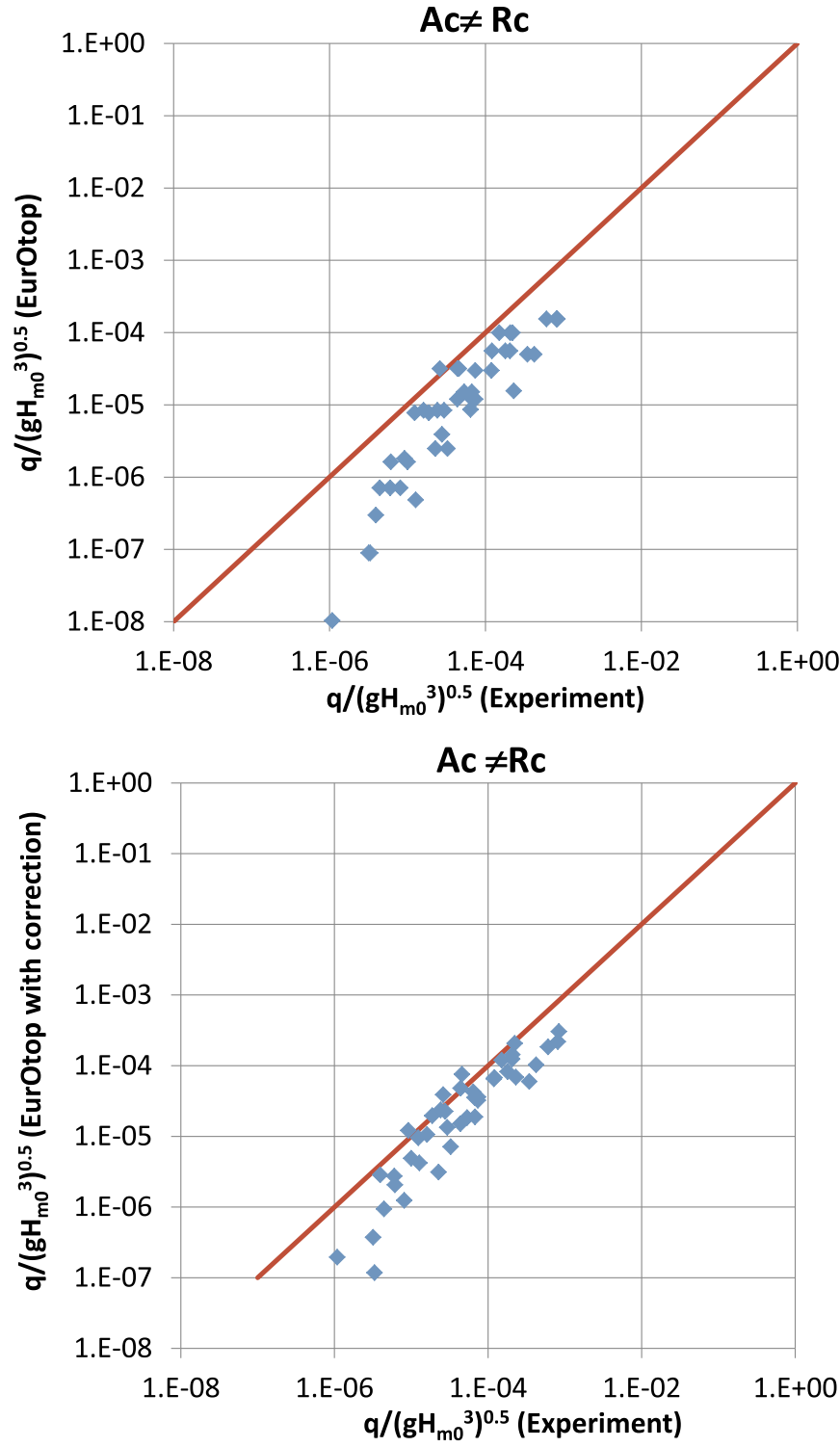

Fig. 17. Comparison of experimental results with EurOtop (2016) (above) and the correction factor, $C_{A c}$ (Eq. (10)) applied EurOtop (2016) (below) for $A_{c} \neq$ $\mathrm{R}_{\mathrm{c}}$ cases.

\section{Funding}

This research did not receive any specific grant from funding agencies in the public, commercial, or not-for-profit sectors.

\section{Acknowledgements}

Turkish Ministry of Transport, Maritime Affairs and Communications, General Directorate of Infrastructure Investments is acknowledged due to providing experimental facility for this study. Gulsen Kiziroglu from Turkish Ministry of Transport, Maritime Affairs and Communications are acknowledged for her contributions to the physical model tests.

\section{Appendix A. Supplementary data}

Supplementary data to this article can be found online at https:// doi.org/10.1016/j.oceaneng.2018.09.043.

\section{References}

Aminti, P., Franco, L., 1988. Wave overtopping on rubble mound breakwaters. In: Proc., 21st Int. Conf. On Coastal Engineering. vol. 1. ASCE, Reston, VA, pp. 770-781.

Besley, P., 1999. Overtopping of Sea-walls-design and Assessment Manual. Environment Agency, Bristol, UK R \& D Technical Report 178.

Bradbury, A.P., Allsop, N.W.H., 1988. Hydraulic Effects of Breakwater Crown Walls. Design of Breakwaters. Institution of Civil Engineers, Thomas Telford, London, pp. 385-396.

Bradbury, A.P., Allsop, N.W.H., Stephens, R.V., 1988. Hydraulic Performance of Breakwater Crown Walls. Hydraulic Research Institute, Wallingford Report SR 146.

Bruce, T., van der Meer, J.W., Franco, L., Pearson, J.M., 2009. Overtopping performance of different armor units for rubble mound breakwaters. Coast Eng. 56, 166-179.

Coeveld, E.M., Busnelli, M.M., Van Gent, M.R.A., Wolters, G., 2006. Wave overtopping of rubble mound breakwaters with crest elements. In: Proc. 30th Int. Conf. Coastal Engineering, San Diego.

CLASH overtopping neural network tool (http://nn-overtopping.deltares.nl/)(February, 2018).

EurOtop, 2007. Wave Overtopping of Sea Defences and Related Structures-assessment Manual. Pullen, T., Allsop, N.W.H., Bruce, T., Kortenhaus, A., Schüttrumpf, H., Van der Meer, J.W.. www.overtopping-manual.com.

EurOtop, 2016. Manual on Wave Overtopping of Sea Defences and Related Structures. An Overtopping Manual Largely Based on European Research, but for Worldwide Application. Van der Meer, J.W.,Allsop, N.W.H., Bruce, T., De Rouck, J., Kortenhaus, A., Pullen, T., Schüttrumpf, H., Troch, P. andZanuttigh, B.. www.overtoppingmanual.com Pre-release October 2016.

Geeraerts, J., Willems, M., 2004. Final Report on Laboratory Measurements, Ostia, CLASH WP4 Report. Ghent University, Belgium.

Goda, Y., Suzuki, Y., 1976. Estimation of incident and reflected waves in random wave experiments. In: Proc,15th Int. Conf. Coastal Engineering, Hawai, pp. 828-845.

Goda, Y., 2010. third ed. Random Seas and Design of Maritime Structures. Advanced Series on Ocean Engineering, vol. 33 World Scentific Publishing.

Jafari, E., Etemad-Shahidi, A., 2012. Derivation of a new model for prediction of wave overtopping at rubble mound structures. J. Waterw. Port, Coast. Ocean Eng. 42-52. https://doi.org/10.1061/(ASCE)WW.1943-5460.0000099.

Kortenhaus, A., Medina, J., González-Escrivá, J., Garrido, J., 2004. Final Report on Laboratory Measurements, Zeebrugge, CLASH WP4 Report. Leichtweiß Institute for Hydraulics, Technical University of Braunschweig, Germany.

Medina, J.R., Molines, J., Gómez-Martín, M.E., 2014. Influence of armour porosity on the hydraulic stability of cube armour layers. Ocean Eng. 88, 289-297.

Molines, J., Medina, J.R., 2015a. Calibration of overtopping roughness factors for concrete armor units in non-breaking conditions using the CLASH database. Coast Eng. $96,62-70$.

Molines, J., Medina, J.R., 2015b. Explicit wave-overtopping formula for mound breakwaters with crown walls using CLASH neural network-derived data. J. Waterw. Port, Coast. Ocean Eng. 142 (3), 04015024.

Owen, M.W., 1980. Design of Seawalls Allowing for Wave Overtopping. Report No. EX 924. HR Wallingford, United Kingdom.

Pearson, J., Bruce, T., Franco, L., Van der Meer, J., Falzacappa, M., Molino, R., 2004. Report on Additional Tests, Part B: Standard Tests for Roughness Factors. CLASH WP4 Report. University of Edinburgh, UK.

Pedersen, J., Burcharth, H.F., 1992. Wave forces on crown walls. In: Proc., 23rd Int. Conf. Coastal Engineering, ASCE, vol. 2. pp. 1489-1502.

Pedersen, J., 1996. Wave Forces and Overtopping on Crown Walls of Rubble Mound Breakwaters. Series Paper 12. Hydraulic and Coastal Engineering Laboratory. Department of Civil Engineering, Aalborg University, Denmark.

Schlüttrumpf, H., Van der Meer, J.W., Kortenhaus, A., Bruce, T., Franco, L., 2010. Wave run-up and wave overtopping at armored rubble slopes and mounds. In: Kim, Young C. (Ed.), Chapter 15 in Handbook of Coastal and Ocean Engineering. World Scientific, pp. 383-409.

TAW, 2002. Technical Report Wave Run-up and Wave Overtopping at Dikes. Technical Advisory Committee on Flood Defence. Author: J.W. van der Meer, The Netherlands).

USACE (United States Army Corps of Engineers), 2007. Coastal Engineering Manual. USACE, Washington,DC Engineer manual 1110-2-1100.

Van der Meer, J.W., Janssen, W., 1995. Wave run-up and wave overtopping at dikes. In: Wave Forces on Inclined and Vertical Wall Structures," Kobayashi and Demirbilek. American Society of Civil Engineers, pp. 1-27.

Van der Meer, J.W., Pullen, T., Allsop, N.W.H., Bruce, T., Schüttrumpf, H., Kortenhaus, A., 2010. Prediction of overtopping. In: Kim, Young C. (Ed.), Chapter 14 in Handbook of Coastal and Ocean Engineering. World Scientific, pp. 341-382.

Van Gent, M.R.A., Van den Boogaard, H.F.P., Pozueta, B., Medina, J.R., 2007. Neural network modelling of wave overtopping at coastal structures. Coast. Eng. 54 (8), $586-593$.

Verhaeghe, H., 2005. Neural Network Prediction of Wave Overtopping at Coastal Structures. Ph.D. Thesis. Universiteit Gent, Gent, Belgium ISBN 90-8578-018-7. 